\author{
مديريت آبيارى قطرهاى زيرسطحى نخيلات در مناطق خشك و نيمهخشى \\ نادر سلامتى '، حسين دهقانى سانيج ' و ليلا بهبهانى

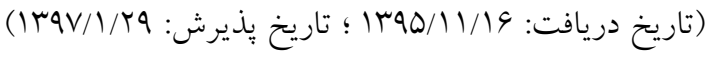

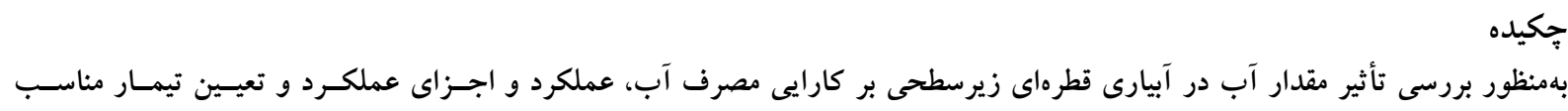

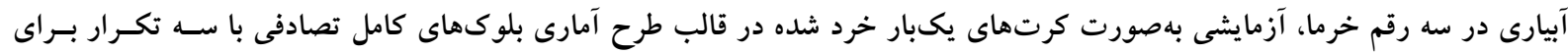

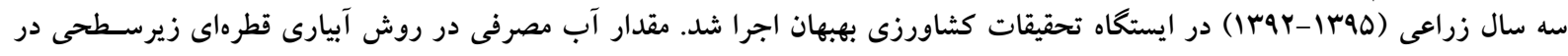

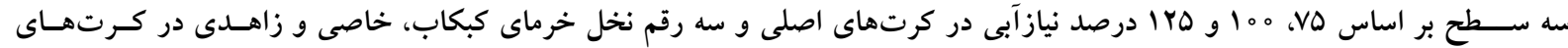

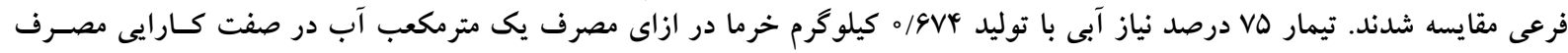

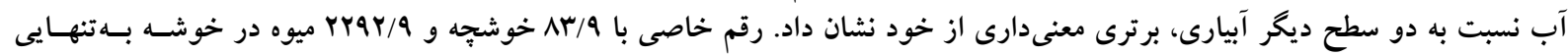

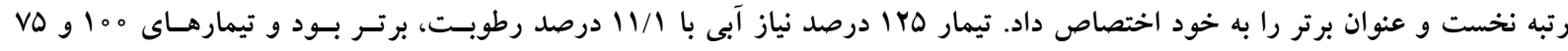

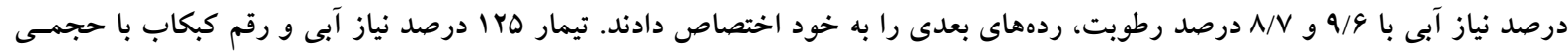

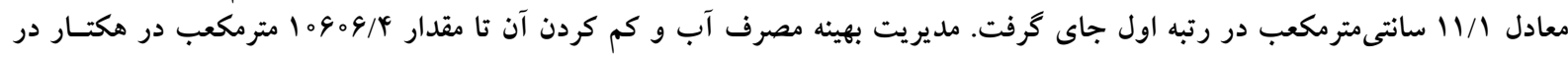

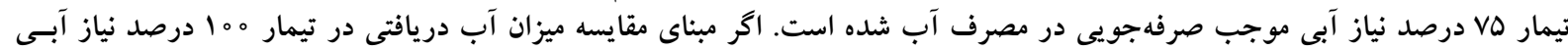

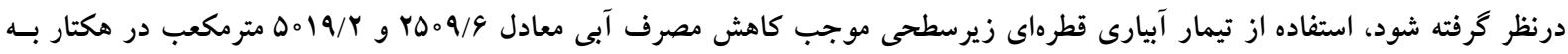

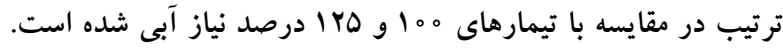

$$
\text { وازههاى كليدى: عملكرد، كارايى مصرف آب، خرما }
$$

\footnotetext{
ا. استاديار يزوهش، بخش تحقيقات فنى و مهندسى كشاورزى، مركز تحقيقات و آموزش كشاورزى و منابع طبيعى خوزستان، سـازمان تحقيقـات،

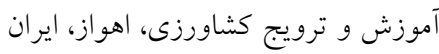

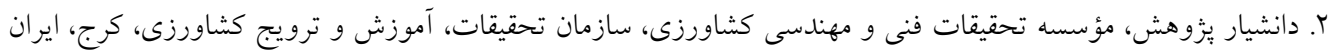

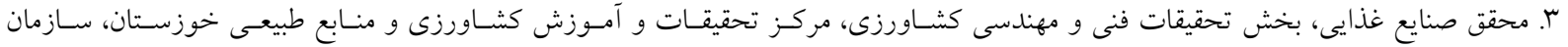

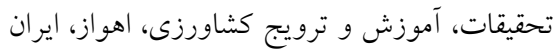

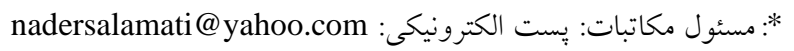


لولههاى جانبى و لوازم كودآبيارى حل شده است. نتايج حاصل

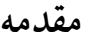

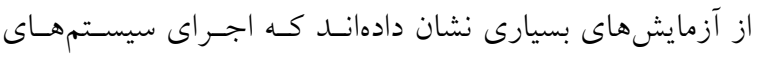

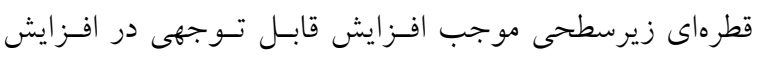

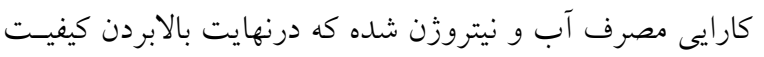

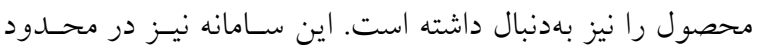

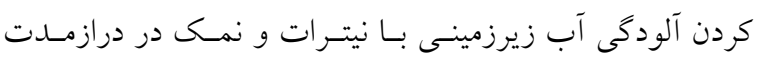

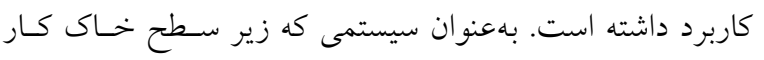

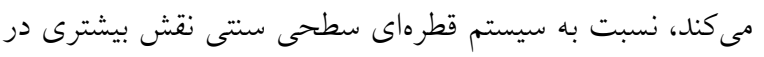

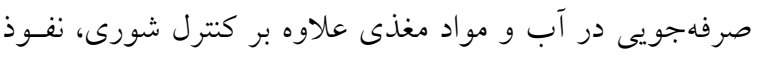
عمقى و دوام سيستم بازى مى كند، اين امر ممكن است بـهدليل سطح خيس شده كروى آب زير سطح خاك در مقايسه با سطح ونح نيمكروى زير قطرهجهانهاى سطحى باشد (Y.).

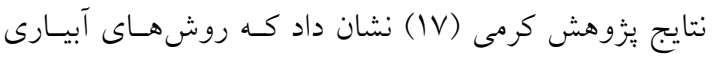
كرتى ساز كار با سيستمهاى توليد سـنتى اسـت. بـا ايـن حسال،

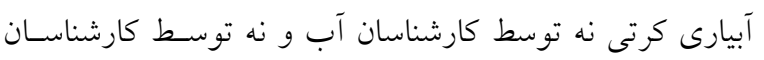

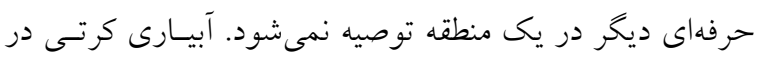

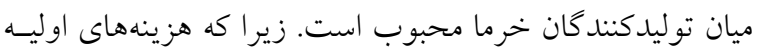

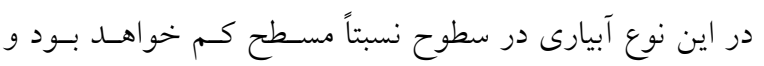

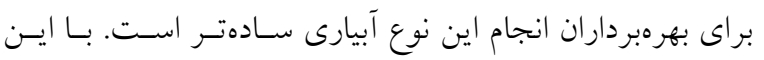

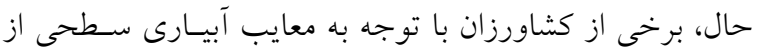

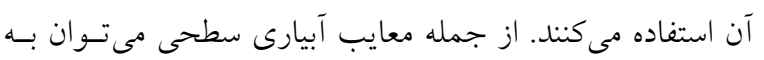

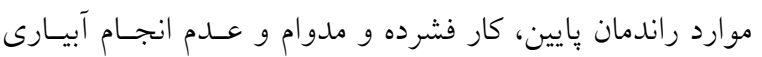

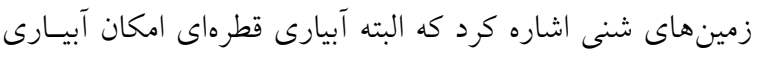

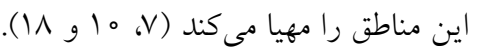

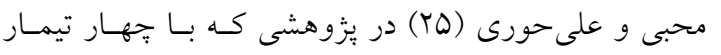
آبيارى شامل روش آبيارى سطحى و قطرهاى با ميزان آب معادل

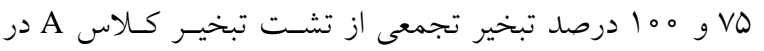

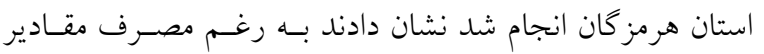

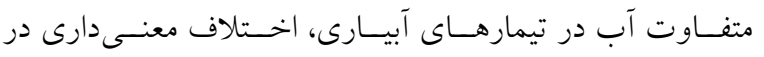
عملكرد ميوه، صفات رويشى و سطح سايهانداز وجود نداشـت.

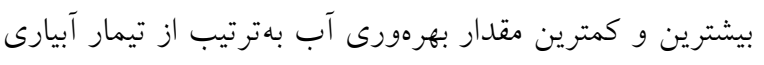

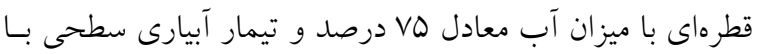

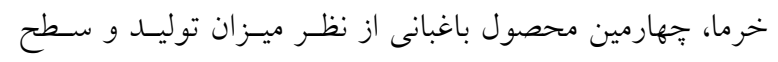

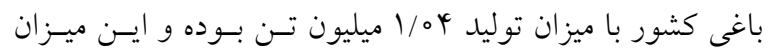

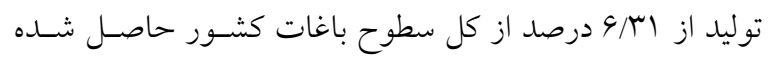

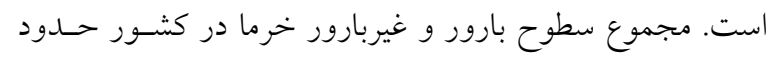

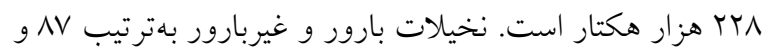

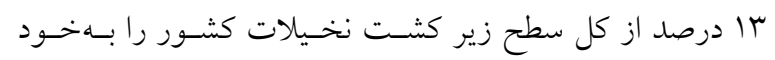

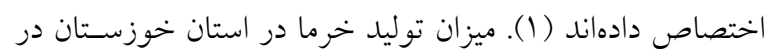

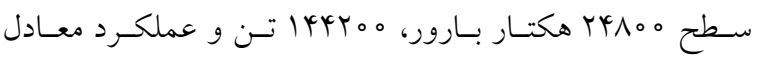

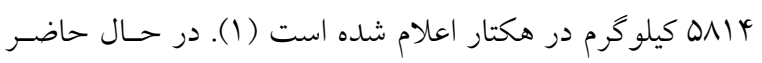

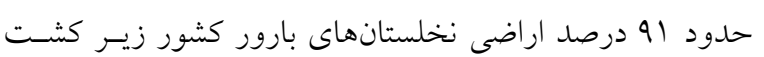

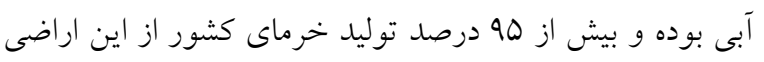

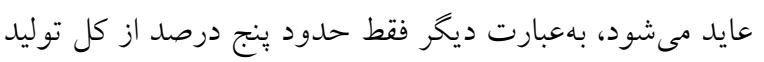

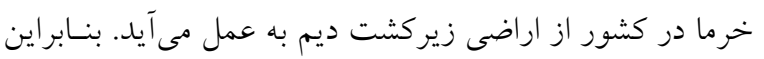

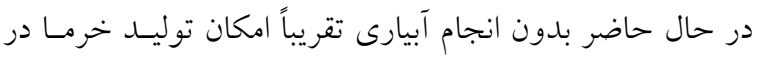
كشور وجود ندارد، زيرا كه سهم توليد از اراضى ديم اولاً بسيار

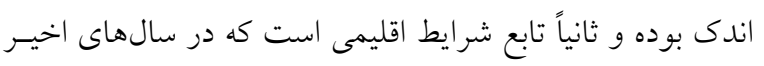

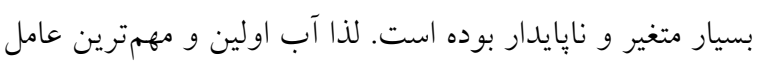

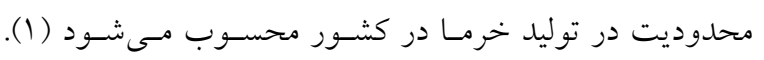

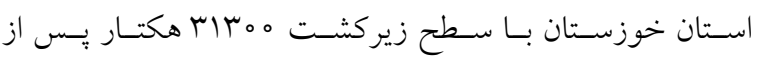
استانهاى سيستان و بلوجستان و بوشهر يكى از منساطق عمسـده

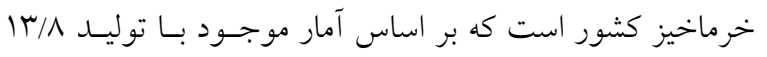
درصد از كل خرماى كشور در رتبه سوم قرار كرفته است (1)

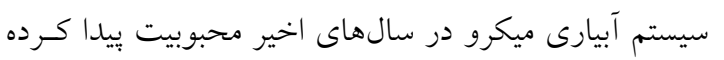

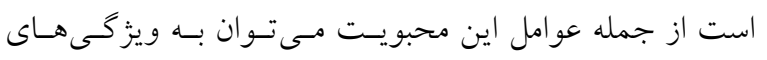

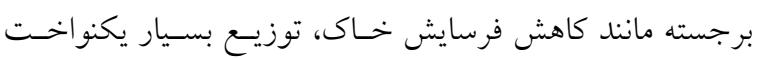

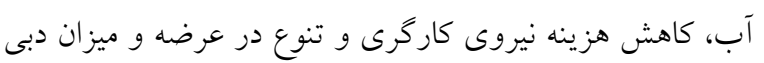

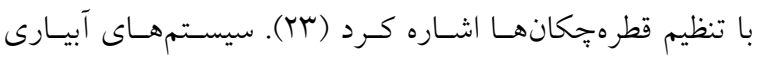
قطـرهاى زيرسـطحى داراى خصوصسيات بهـرهورى و رانسـدمان

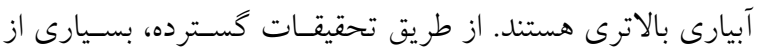

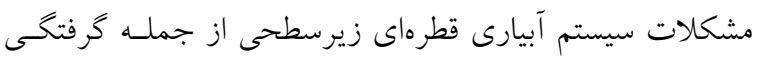

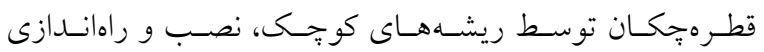


هاى آبيارى مناسب و كاهش تنش در تخليه منابع آب زيرزمينى

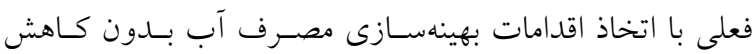

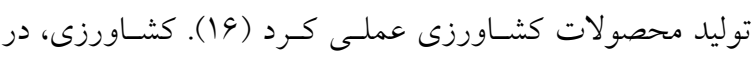

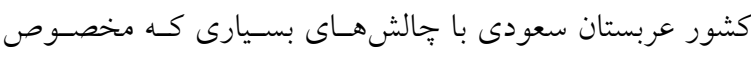

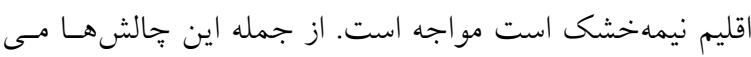

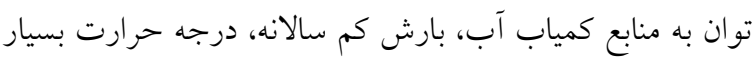

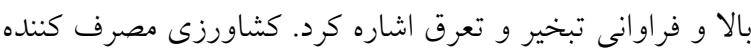

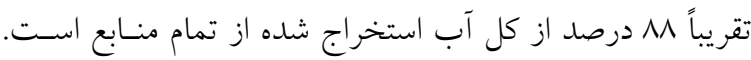

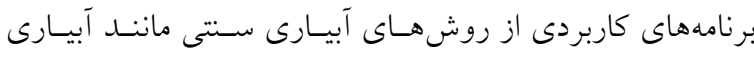

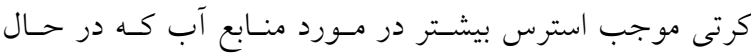
حاضر رو به كاهش هستند مىشود (9 و و (1)). نتايج تحقيق محبى (TY) در مورد مقايسـه اثـرات دو ميـزان

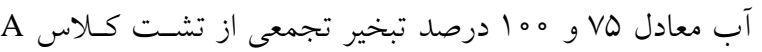
در دو روش قطرهاى و سطحى روى رشد و نمو نخـل خرمساى رقم بيارم نشان داد كه بين تيمارهاى مختلف بـه لحساظ برخسى

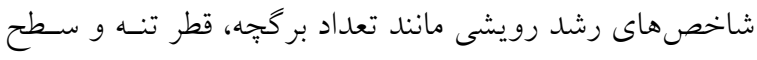
سايهانداز اختلاف معنى دارى وجود داشـته اسـت. ولسى از نظـر

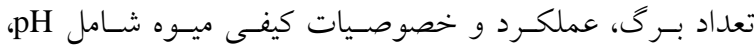
رطوبت، مواد جامد محلول و قند كل ميوه، تفاوت بين تيمارهـا

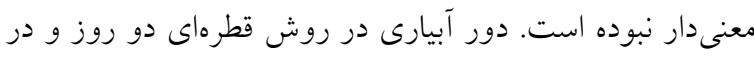
روش سطحى هفت روز بود. همجنين نتايج نشان داد كه اكرجهه

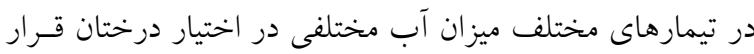
كرفت ولى از لحساظ عملكــد و صـفات كيفس ميسوه اخستلاف

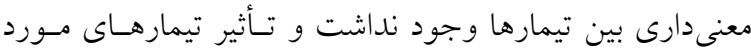
آزمايش بر صفات رويشى و عملكرد محصـول معنسىدار نبـود، مصرف آب در تيمار VD درصد تبخير در روش قطرهاى حسدود

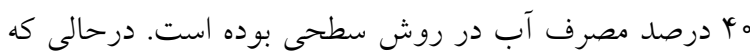
از لحاظ آمارى اختلاف معنىدارى بين عملكرد محصول خرمـا

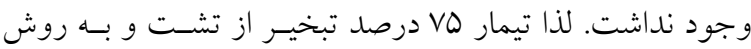

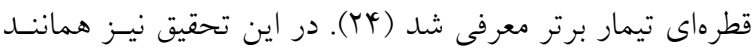

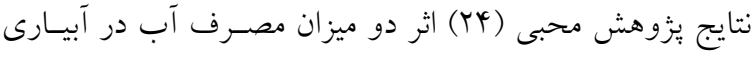

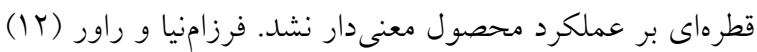

ميزان آب معادل ه 1 درصــ تبخيــر تجمعس از تشـت تبخيـر

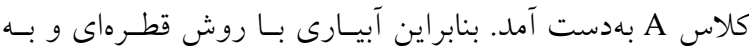

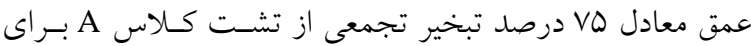

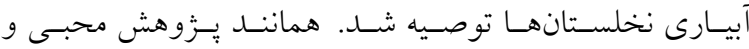

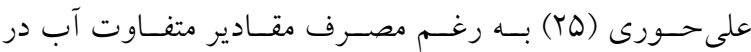

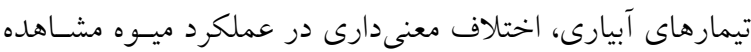
نشد. همجنين همانند تحقيق فوق، بيشسترين بهـرهورى مصسرف آب به ازاى تيمارهايى كه در آنها ها درصد كم آبيـارى اعمـال

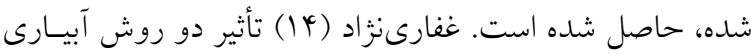

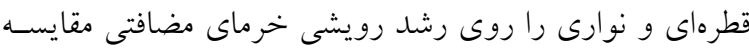

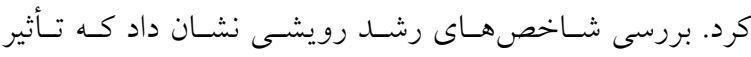

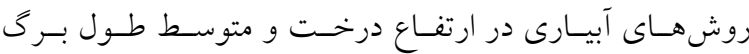

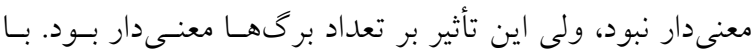

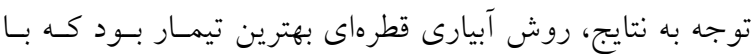
مصرف آب كمتر، بيشترين رشد رويشى را موجب شد.

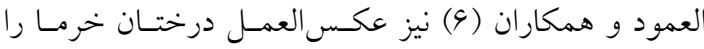

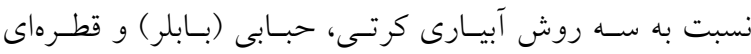
بررسى كردهاند. نتايج اين مطالعه نشان داد كه بيشترين عملكرد محصول و كارايى مصـرف آب بـه سيستم آبيـارى قطـرهاى و

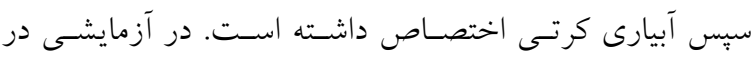

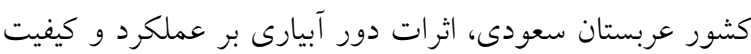

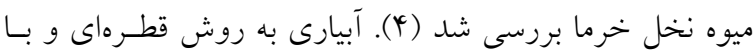

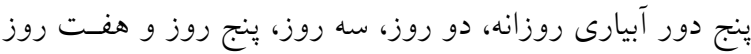

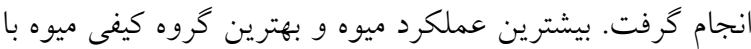

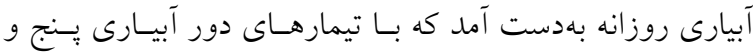
هفت روز تفاوت معنى دارى داشت. آزمايشهاى متعـدد انجـام

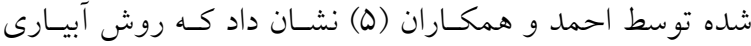
قطرهاى زيرسطحى داراى بُّانسيل بزرگى در غلبه بر كمبـود آب

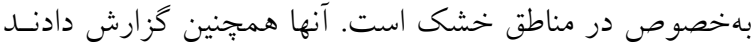
كه نيـاز بـه حفـظ تعـادل بـين منـابع آب و توليــ محصـولات

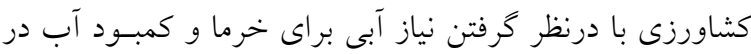

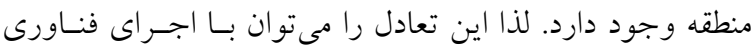


ضرورى و اجتناب نايذير است. لذا با انجام اين يُزوهش امكـان

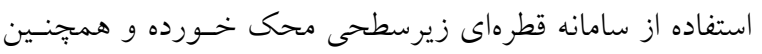

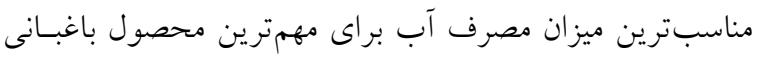

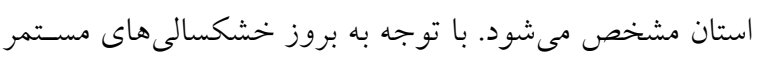

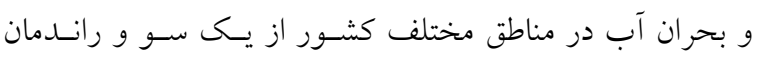

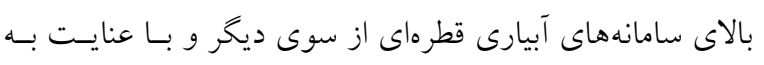

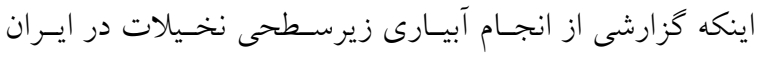

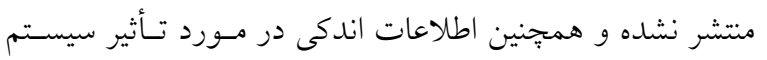
هاى آبيارى قطرهاى زيرسطحى بر نخيلات موجود اسـت، ايسن

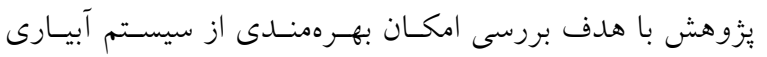

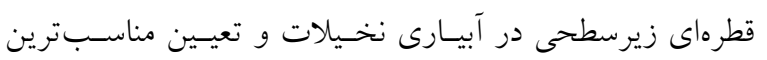

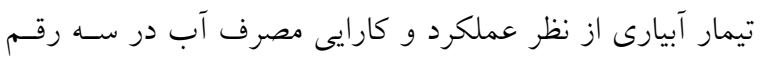
كبكاب، خاصى و زاهدى صورت گرفت.

\section{مواد و روشها - ماد} بهمنظور بررسى تأثير مقدار آب در آبيارى قطرهاى زيرسطحى بر

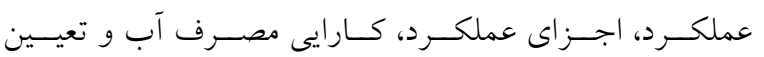
مناسبترين تيمار آبيارى سه رقم نخل خرماى كبكاب، خاصى آمس

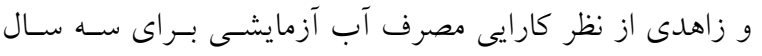

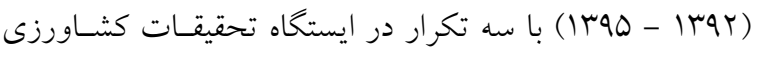

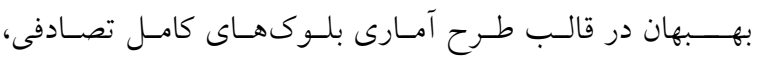

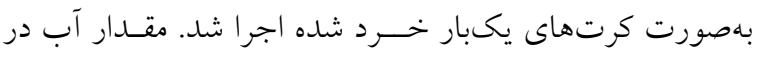

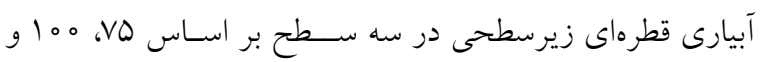

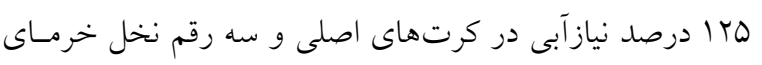

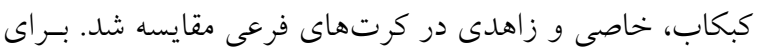

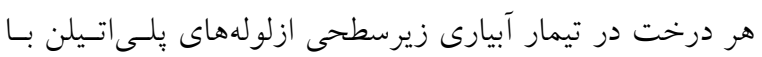

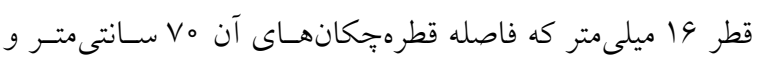

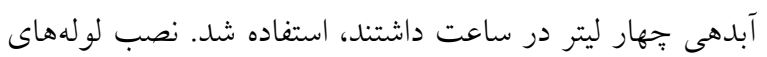

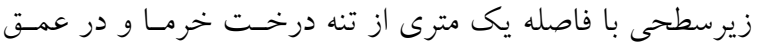

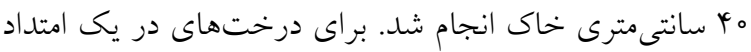

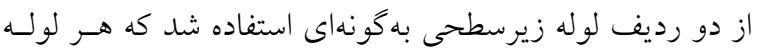

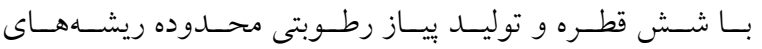

تأثير كم آبيارى روى درختان بارور خرماى رقـم مضـافتى را بـا

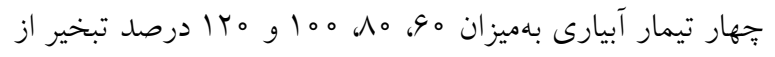
تشت كلاس A بررسى كردند. بيشسترين و كمتسرين عملكـرد از

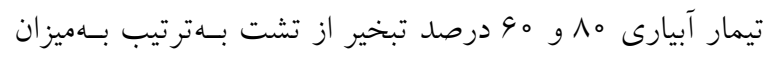

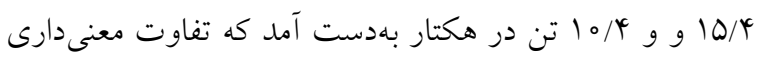

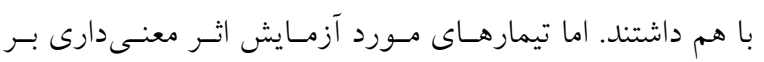

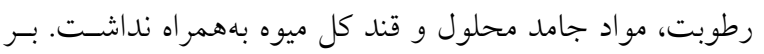

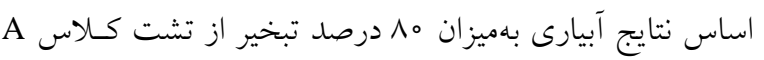
بهعنوان يك روش مديريتى در آبيارى نخلستانهاى بــم توصسيه

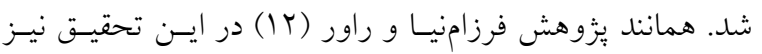

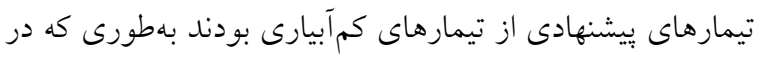

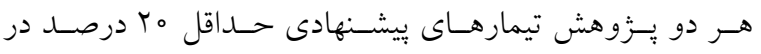

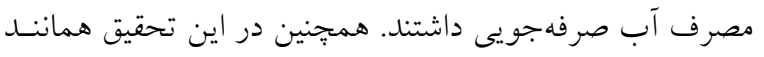

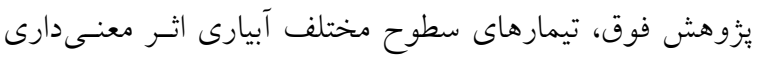

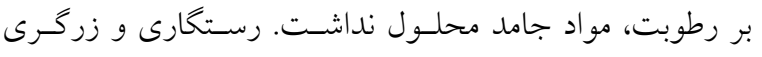

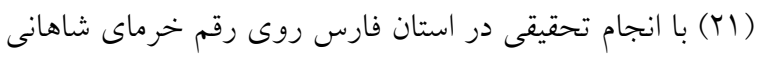

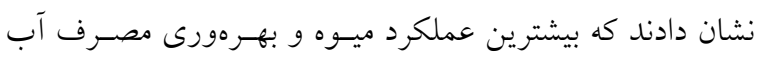

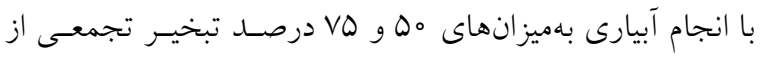
تشت كلاس A بهترتيب در فصل بهار و بقيه ايام سـال حاصل بهل

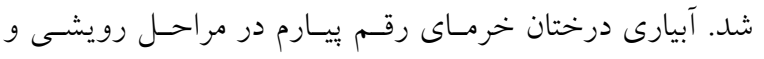
زايشى نشان داد كه اختلاف معنى دارى از نظر صفات رويشى نظير تعداد برگ و بر گجهه، محيط تنه، سطح سايهانداز و عملكرد

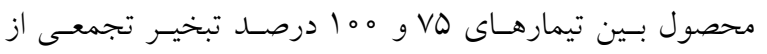
تشت كلاس A وجود نداشت. بيشترين بهرهورى مصـرف آب، تيمارهـائ

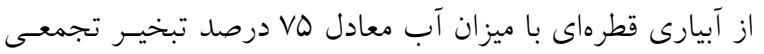

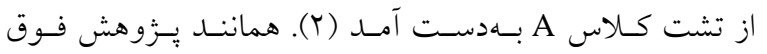

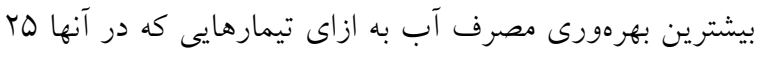
درصد كمآبيارى اعمال شده، حاصل شده است.

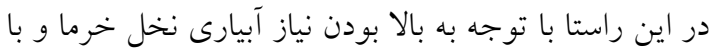

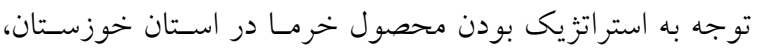
لزوم اجراى طـرحهـاى تحقيقـاتى در مـورد امكــان استفاده از

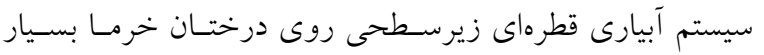


جدول ا. ضريب گياهى خرما در ماهاى انجام آبيارى

\begin{tabular}{|c|c|c|c|c|c|}
\hline شهريور & مرداد & تير & خرداد & ارديبهشت & فروردين \\
\hline 1 & 1 & 1 & $0 / 9 \mathrm{~V}$ & $0 / 94$ & $0 / 91$ \\
\hline
\end{tabular}

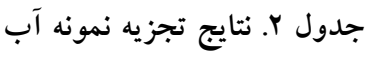

\begin{tabular}{|c|c|c|c|c|c|c|c|c|c|c|}
\hline \multicolumn{3}{|c|}{ آنيونها (meq/l) } & \multicolumn{3}{|c|}{ كاتيونها (meq/l) } & \multirow{2}{*}{$\begin{array}{l}\text { T.D.S } \\
\text { (mg / lit) }\end{array}$} & \multirow{2}{*}{$\mathrm{pH}$} & \multirow{2}{*}{$\begin{array}{c}\text { EC } \\
(\mu \mathrm{S} / \mathrm{cm})\end{array}$} & \multirow{2}{*}{ منبع آبدهى } & \multirow{2}{*}{ رديف } \\
\hline $\mathrm{Cl}^{-}$ & $\mathrm{SO}_{4}^{-r}$ & $\mathrm{HCO}_{r}^{-}$ & $\mathrm{Na}^{+}$ & $\mathrm{mg}^{\Upsilon+}$ & $\mathrm{Ca}^{\mathrm{r+}}$ & & & & & \\
\hline $\mid r / 0$ & - & $r / 0$ & $14 / 0$ & $9 / 0$ & $11 / 0$ & - & $\mathrm{V} / \mathrm{o}$ & $\mu \circ \Lambda_{0}$ & جاه & 1 \\
\hline
\end{tabular}

جدول r. مشخصات بافت خاى

\begin{tabular}{|c|c|c|c|c|}
\hline بافت & رس (.) & سيلت (.\%) & شن (\%) & $\begin{array}{c}\text { عمت خاك } \\
(\mathrm{cm})\end{array}$ \\
\hline silty clay & pr & $\psi \wedge$ & 9 & سח-0 \\
\hline silty clay & 49 & 48 & 0 & Mr-99 \\
\hline silty clay & id & ఎ. & 0 & $99-100$ \\
\hline
\end{tabular}

نوع طرح آزمايشى توسط نرمافزار آمارى MSTATC مورد تجزيه

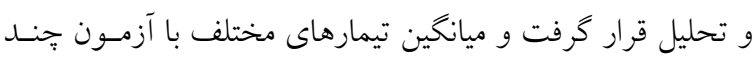
دامنهاى دانكن مقايسه شد. براى مديريت دقيق آبيارى، با استفاده از آمار روزانـه ايستـعاه هواشناسى سينويتيك به.بهان (دمـاى حسداقل و حسـاكثر روزانـه، رطوبت حداقل و حداكثر روزانه سـرعت بـاد و حسـاكثر سـاعات

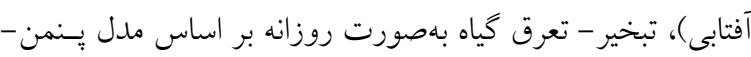

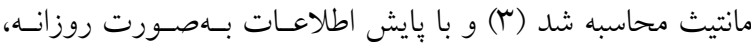

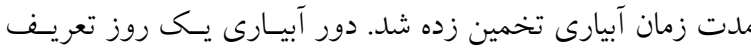
شد و براى تعيين ضرايب كياهى ترجيحاً بر اساس مطالعات انجام

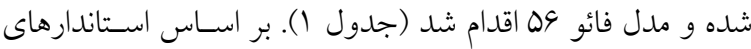

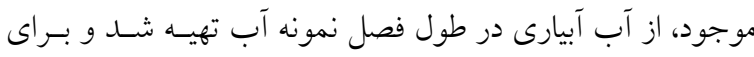

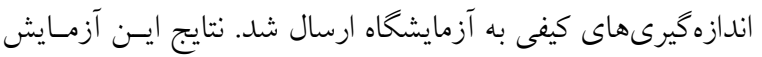
در جلدول (r) نشان داده شده است. نتـايج آزمايشـات تعيسين تعيسين خصوصسيات فيزيكسى و

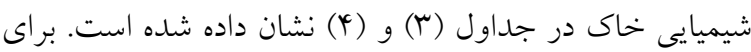
اندازهيرى صفات كيفى رطوبت نمونهها در خشكىكن خهلأ در
مؤثر را مرطوب مىكرد. درختـان بـا فاصـله NXVم متـرى در سـال 1\%9 بهصورت باجوش غرس شدهاند. به عبارت ديخر با آبيـارى زيرسطحى، هر درخت، ^^ ليتر آب در ساعت دريافت مى كند كـه له

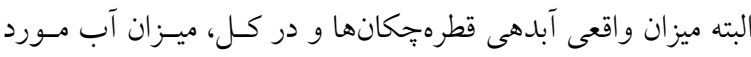
استفاده هر رديف لوله زيرسطحى، توسط كتور با دقت يـك دهـم ليتر كه در ابتداى هر خط آبيارى زيرسطحى قرار داشت، ثبت شد.

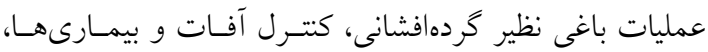
حذف باجوش و تعديل نسبت برگ به خوشه براى كليه تيمارهـا يكسان انجام شد. در زمان برداشت، محصول درختان خرمايى كه براى يك تيمار درنظر كرفته شده بود، بهصـورت كامـل برداشـت بـت شده و به نسبت عملكرد در هكتار براى آن تيمـار محاسـبه شــده است. سبس با انتخاب تصادفى حدود يكى كيلـو گرم از محصـول

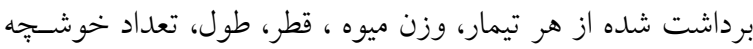

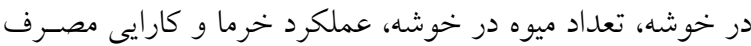

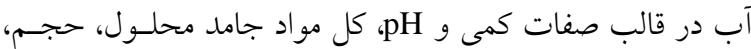
رطوبت، سفتى بافت و قند ميـوه در قالـب صـفات كيفى مـورد بررسى قرار كرفت. سبس كليه شاخصهاى مذكور بـا توجـهـ بـهـ 


\begin{tabular}{|c|c|c|c|c|c|c|c|c|c|c|c|c|}
\hline \multicolumn{13}{|c|}{ جدول f. برخى مشخصات شيميايى نمونه خاى } \\
\hline \multirow{2}{*}{ كاتيونها } & \multicolumn{4}{|c|}{ كاتيونها (meq/lit) } & \multirow{2}{*}{ آنمع } & \multicolumn{4}{|c|}{ 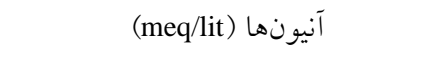 } & \multirow{2}{*}{$\mathrm{pH}$} & \multirow{2}{*}{$\begin{array}{c}\text { EC } \\
(\mathrm{dS} / \mathrm{m})\end{array}$} & \multirow{2}{*}{$\begin{array}{c}\text { عمق خاى } \\
\text { (cm) }\end{array}$} \\
\hline & $\mathrm{Mg}^{r_{+}}$ & $\mathrm{Ca}^{r+}$ & $\mathrm{Na}^{+}$ & $\mathrm{K}^{+}$ & & $\mathrm{CO}_{r}^{-r}$ & $\mathrm{HCO}_{r}^{-}$ & $\mathrm{Cl}^{-}$ & $\mathrm{SO}_{4}^{-r}$ & & & \\
\hline$|Y / V|$ & $r / V Q$ & $9 / T \Delta$ & $r / V I$ & - & $|r / 9|$ & - & 10 & $r / D$ & $1 / 11$ & $\mathrm{~V} / \wedge \mathrm{Q}$ & $0 / 1 T$ & سותים \\
\hline $01 / 0 r$ & 10 & $M T / T Q$ & $9 / V \wedge$ & - & $r \omega / r$ & - & $9 / \pi \Delta$ & r/VQ & $r Q / T_{0}$ & $V / 91$ & $T / Y Y$ & M-99 \\
\hline $01 / 94$ & $V / D$ & r。 & $14 / 14$ & - & Tr/VG & - & $V / 0$ & 0 & To/TG & $\mathrm{V} / \Lambda \mathrm{V}$ & $r / D 1$ & $99-100$ \\
\hline
\end{tabular}

آبيارى، رقم و اثرات متقابل آنهـا در صـفات قطـر و طـول نيـز معنى دار نشد. در شاخص درصد خشكيدكى خوشه خرما اثرات سطوح آبيارى معنى دار نشد ولى اثر رقم در سطح يك درصد و اثر متقابل آنها در سطح ينج درصد معنىدار شد. در صفت تعداد خوشجه در خوشه اثرات سطوح آبيارى و اثرات متقابل سـطوح آبيارى و رقم معنى دار نشد ولى اثر رقم در سـطح يـك درصسـ معنى دار شد. در شاخص تعداد ميوه در خوشسه اتــرات سـطوح آبيارى معنى دار نشد ولى اثر رقم و اثر متقابل آنها در سطح يـنج درصد معنى دار شدند. در صفت عملكرد اثرات سطوح آبيـارى، رقم و اثرات متقابل آنها معنىدار نشد. در صفت كارايى مصرف آب اثرات سطوح آبيارى در سطح يك درصد معنىدار شد ولى اثرات رقم و اثرات متقابل سـوح آبسى و رقـم معنسىدار نشـد (جدول 9). نكته قابل توجسه در جـدول تجزيسه واريـانس، اثـر

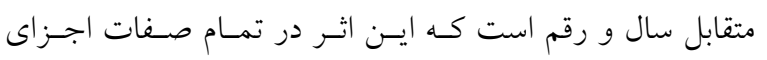
عملكرد، عملكرد و كارايى مصرف آب معنىدار شده است. اين معنى دار شدن مىتواند بيانكر سال آورى محصول باشـد كـه در

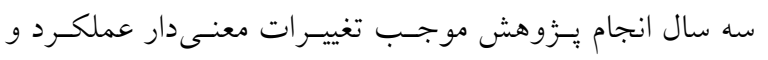
اجزاى عملكرد شده است (جدول 9). مقايسه ميانخين شاخصهاى وزن ميوه، قطر، طـول، درصــ خشكيدكى خوشه، تعداد خوشهُه در خوشـه، تعـداد ميسوه در خوشه و عملكرد در تيمارهاى سطوح مختلف آبى نشان داد كه هيج يك از تيمارهاى آبيارى، برترى معنى دارى نسبت به هم در صفات فوق نداشتند. فقط در شاخص كارايى مصـرف آب ايسن

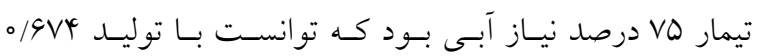

دماى م V درجسه سـانتى گـــاد مطـابق روش اسـتاندارد AOAC

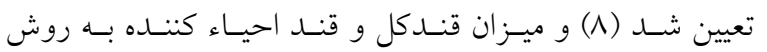
فهلينگ تعيين شد (Q) (1). به اين منظور از هر تكرار يـك نمونسه با اندازه يكسان انتخاب شده و نيـروى مـورد نيـاز بــراى نفـوذ يروب به قطر 1/9 ميلى متر و با سرعت ه/ 1/ ميلى متـر بــر ثانيسه

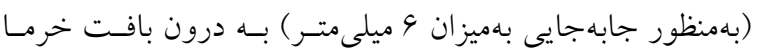
اندازه گيرى شد (19). مو اد جامد محلـول (TSS) بـا اسـتفاده از

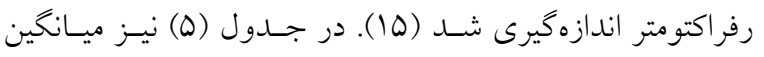
مقادير آب مصرقى تيمارهاى مختلف در سه سال انجام تحقيـق كه از پانزده فروردين ماه تا بيست و وِـنجم شهـريور مـاه ادامسه داشته نشان داده شده است. كارايى مصرف آب از تقسيم عملكرد بر مجموع آب مصسرف شده توسط آبيارى و بارندگى مؤثر بر اساس محاسبه شـد معادلـه (1) و بارندكى مؤثر از معادله SCS معادله (Y) تعيين شد (YY). $\mathrm{WUE}=\frac{\mathrm{Y}}{\mathrm{Pe}+\mathrm{Ir}}$

$P e=P \times \frac{(1 r \Delta-(\circ / r \times P))}{1 r \Delta}$

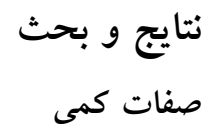
نتايج تجزيه واريـانس تيمارهـاى مختلـف آبيـارى، رقـم و اثـــ متقابل آنها نشان داد در شاخص وزن ميوه، اثرات سطوح آبيارى و اثر متقابل سطوح آبيارى و رقم معنىدار نشد ولى اثر رقـم در سطح يك درصد معنى دار شد جدول (9). اثرات سطوح مختلف 


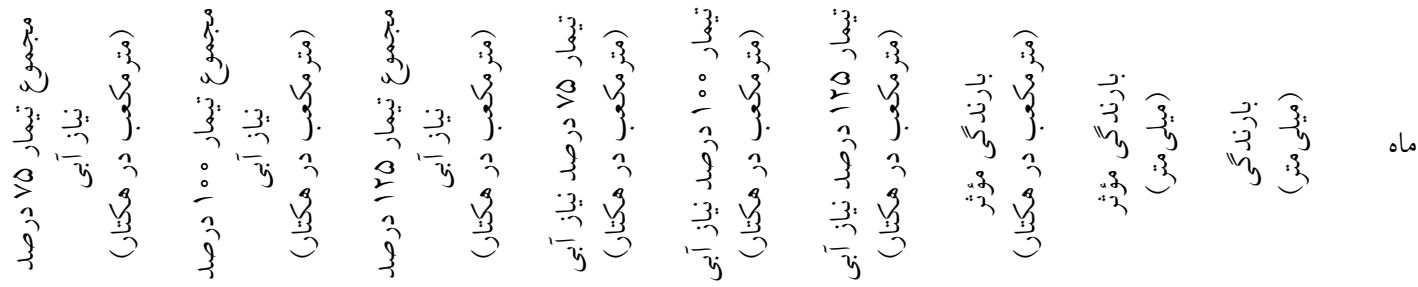

\begin{tabular}{|c|c|c|c|c|c|c|c|c|c|}
\hline $149 / 9$ & $49 / 9$ & $49 / 9$ & $\circ$ & 。 & $\circ$ & $49 / 9$ & $Q / \circ$ & $0 / 0$ & مهر \\
\hline$\Delta \Delta 1 / \Gamma$ & $\Delta 01 / \pi$ & $\Delta \Delta 1 / \Gamma$ & $\circ$ & $\circ$ & $\circ$ & $\Delta \Delta 1 / \mu$ & $\Delta Q / 1$ & $91 / 1$ & آبان \\
\hline$\Lambda \omega \circ / T$ & $\Lambda \Delta \circ / T$ & $\Lambda \Delta \circ / r$ & 。 & $\circ$ & 。 & $\Lambda \omega \circ / \Gamma$ & $\Lambda \Delta / \circ$ & $101 / 0$ & آذر \\
\hline $199 / 0$ & $199 / 0$ & $199 / 0$ & $\circ$ & $\circ$ & $\circ$ & $199 / 0$ & $19 / 9$ & $104 / 9$ & دى \\
\hline $119 / 9$ & $119 / 9$ & $119 / 9$ & 。 & $\circ$ & 。 & $119 / 9$ & $1 Y / 0$ & $I T / Y$ & بهمن \\
\hline mo/l & חסק & mo/l & 。 & 。 & 。 & & r $/ 0$ & $\mathrm{rQ} / \mathrm{o}$ & اسفند \\
\hline VYN/G & $\Lambda M / V$ & loYN/A & $\varphi \wedge \circ / \mu$ & $940 / 4$ & $100 / 9$ & $Y Y \Lambda / T$ & $T Y / A$ & $r Q / Q$ & فروردين \\
\hline $11 \mathrm{~V} / \mathrm{s}$ & $1099 / 9$ & $1991 / 9$ & $11 V 0 / 9$ & $109 \mathrm{~V} / 9$ & $1909 / 9$ & $1 / V$ & $0 / r$ & $0 / r$ & ارديبهشت \\
\hline $1091 / 0$ & $r \mid r \circ / V$ & $r G 9 M / 4$ & $1091 / 0$ & $r \mid r \circ / V$ & $r G 94 / 4$ & 。 & 。 & 。 & خرداد \\
\hline IVTr/。 & rraY/l & $r \wedge 90 / 1$ & $|V| r / \mid$ & $r Y \wedge Y / I$ & $r \wedge \Delta \Delta / l$ & $10 \%$ & $1 / 0$ & $1 / 0$ & تير \\
\hline $1011 / \mathrm{V}$ & $Y \circ Y Y / Q$ & TOYG/T & $1011 / 4$ & $r 010 / Y$ & $r 019 / 0$ & $V / r$ & $\circ / V$ & $\circ / V$ & مرداد \\
\hline $1094 / 1$ & $\mid k x / 1$ & $\mid V q r / r$ & $1000 / 1$ & $1400 / 1$ & $I V D \circ / 1$ & 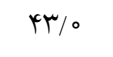 & $\mu / \mu$ & $\varphi / \mu$ & شهريور \\
\hline $10909 / 4$ & $|\mu| 19 / 0$ & IOGYQ/G & VOTN/A & 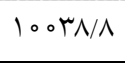 & ITEYANO & $r \circ V V / 9$ & $r \circ v / \Lambda$ & r山०/A & جمع \\
\hline
\end{tabular}

فوق اتفاق افتاده و اين رقم خاصى است كه با 1/4 خوشتهه و

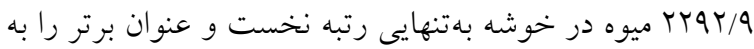
خود اختصاص داد و در نقطه مقابـل رقـم كبكـاب بـود كـه بـا

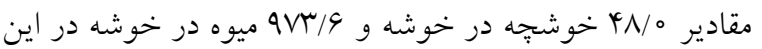
دو صفت كمترين مقادير را به خود اختصاص داده اسـت. نكتسه قابل توجه در صفت عملكرد توجه به اجزاى عملكـردى اسـت كه بيشتر ذكر شد. اين صفات بايد با هـم ديسـده شـوند. تعـداد بيشتر خوشتهه در خوشه موجـب بيشـتر بـودن تعـداد ميسوه در خوشه مىشود. بيشـتر بــودن تعــاد ميـوه در يـك رقـم انتظــار عملكرد بيشتر آن رقم را نويد مىدهد. ولى ميانخين عملكردهاى

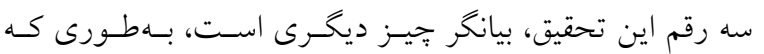
ميانخين عملكردهاى سه رقم اختلاف معنى دارى با هـم ندارنـد.
كيلـو گرم خرمهـا در ازاى مصـرف يـك مترمكعـب آب برتـــى معنى دارى نسبت به دو تيمار ديخـــ از خــود نشـان دهـــ و بــه

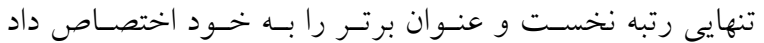

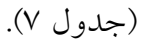

مقايسه ميانحين صفات كمى در سه رقم مورد آزمايش نشان داد رقم برتر در وزن و طول ميوه رقم كبكاب بود كه بهترتيب با مقادير 1 / ا كرم و r/9 سانتى متر برترى معنسى دارى نسـبت بـه دو رقم ديخر داشت و ارقـام زاهـدى و خاصسى بـهترتيـب رده مشترك بعدى را به خود اختصاص دادند و اين رقم خاصى بود

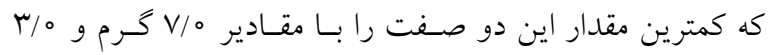
سانتى متر به خــود اختصـاص داد. درحسالى كـه در دو شـاخص تعداد خوشجه در خوشه و تعداد ميوه در خوشه عكسس حالـت 


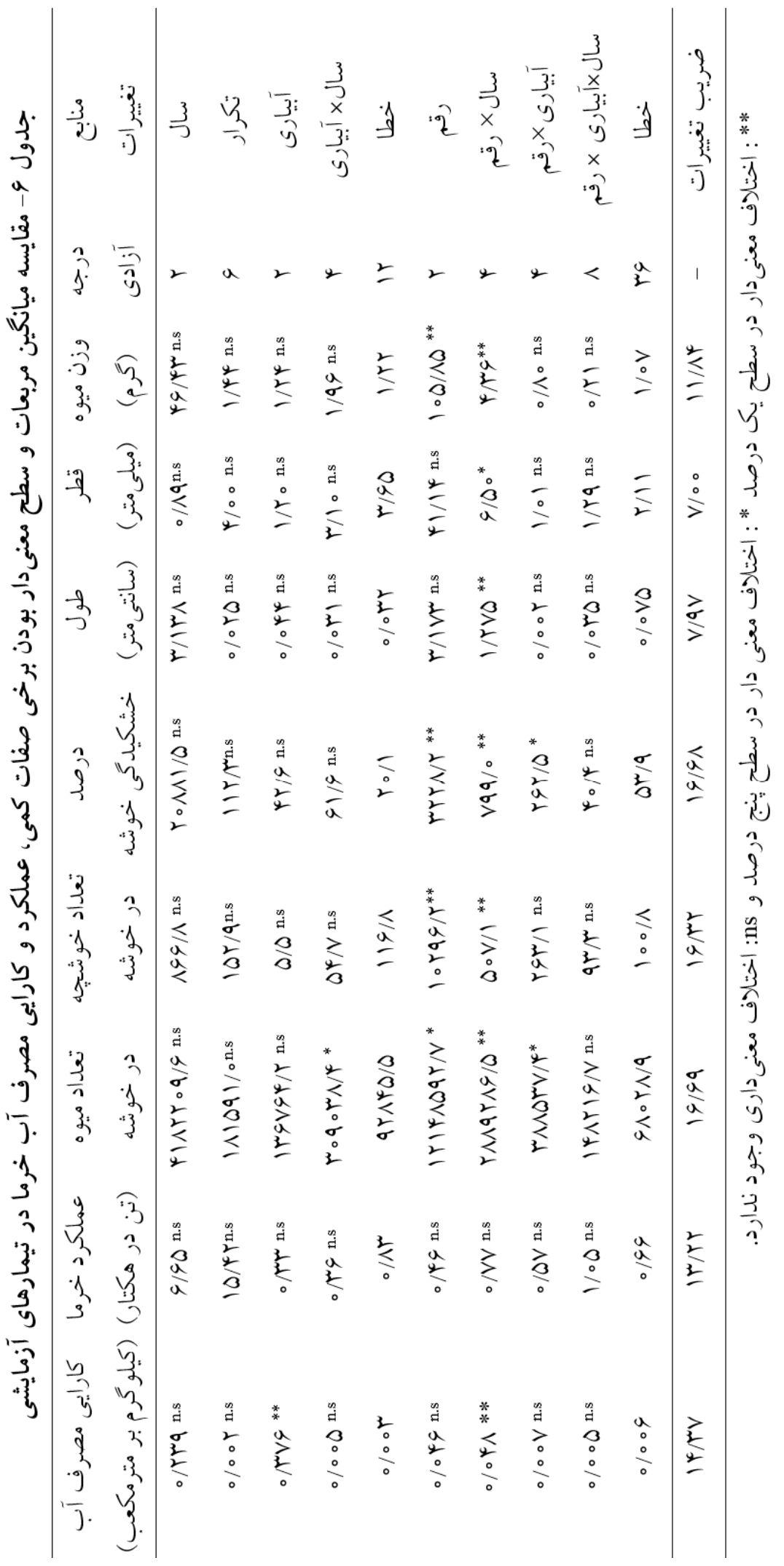


مديريت آبيارى قطرهاى زيرسطحى نخيلات در مناطق خشك و نيمهخشى

جدول V. مقايسه ميانگين برخى صفات كمى و كارايى مصرف آب در تيمارهاى آزمايشى سطوح آبيارى

\begin{tabular}{|c|c|c|c|c|c|c|c|c|}
\hline 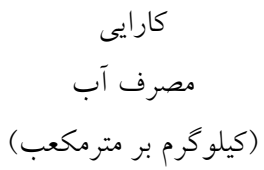 & (تن در هكتار ) غرما & ديوه تعداد & خوشتجه تعداد & خشكيد & 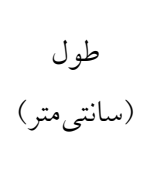 & (ميلى متر) & وزن ميوه & سطوح آبيارى \\
\hline $0 / 9 V y^{4 a}$ & $V / \circ \Delta V^{a}$ & $1491 / 9^{a}$ & $G Y / 0^{a}$ & $r \Lambda / T^{\mathrm{a}}$ & $r / \varphi^{a}$ & $r \circ / 9 a$ & $9 / \circ^{a}$ & Vه درصد نياز آبى VD \\
\hline$\circ / \Delta Y^{b}{ }^{b}$ & G/Arra & $1949 / 9 a$ & $91 / 1^{\mathrm{a}}$ & $r \Delta / q^{a}$ & $r / \varphi^{a}$ & $r \circ / V^{a}$ & $\Lambda / \varphi^{a}$ & هـ مر درد نياز آبى \\
\hline$\circ / y_{0} \circ$ & G/ATra & $100 \circ / V^{a}$ & $91 / 4 a$ & $r \varphi / T^{c a}$ & $r / 4 a$ & $r \mathrm{o}^{\mathrm{a}}$ & $\Lambda / \varphi^{a}$ & هrا درصد نياز آبى \\
\hline
\end{tabular}

در هر ستون اعداد با حروف مشترك در سطح احتمال ينج درصد، اختلاف معنى دارى با هم ندارند.

جدول ^ـ مقايسه ميانخين برخى صفات كمى و كارايى مصرف آب در تيمارهاى آزمايشى سه رقم خرما

\begin{tabular}{|c|c|c|c|c|c|c|c|c|}
\hline (كيلو كرم بر مترمكرف مصرف آب & (تن دمر هكتد خرمار) & تعداد ميوه & 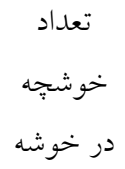 & خشكيد خدى & 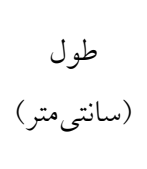 & (ميلى متر ) & وزن ميوه & رقم \\
\hline$\circ / 0 \circ 9^{a}$ & $9 / 499^{a}$ & $9 V / / q^{c}$ & $\nvdash \wedge / \circ^{b}$ & rN/qa & $r / q^{a}$ & $r 1 / q^{a}$ & $10 / 9^{a}$ & كبكاب \\
\hline - $/ \Delta \& q a$ & q/9rra & rrqr/qa & $\wedge r / q^{a}$ & $r \mu / Q^{b}$ & $r / o^{b}$ & $19 / \mathrm{ca}^{\mathrm{a}}$ & $\mathrm{V} / \mathrm{ob}^{\mathrm{b}}$ & خاصى \\
\hline$\circ / \Delta \Lambda^{a}$ & $V / r q l^{a}$ & IKTY/Gb & $\Delta r / G^{b}$ & $\mathrm{IV} / \mathrm{V}^{\mathrm{b}}$ & $\mathrm{r} / \mathrm{\mu b}^{\mathrm{b}}$ & $r \circ / q^{a}$ & $\Lambda / \mu^{\mathrm{b}}$ & زاهدى \\
\hline
\end{tabular}

در هر ستون اعداد با حروف مشترك در سطح احتمال ينج درصد، اختلاف معنى دارى با هم ندارند.

و V/MqI تن خرما در يك هكتار برترى معنى دارى نسبت به هم نداشته و رتبهاى يكسان و مشترك را به خود اختصـاص دادنــد. در صفت كارايى مصرف آب، ارقام كبكاب، خاصسى و زاهـدى

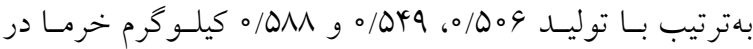
ازاى مصرف يكى مترمكعسب آب رتبـهاى مشـترك را بـه خـود اختصاص دادند (جدول ^). مقايسه ميانگين اثرات متقابل سطوح آبيارى و رقم نشان داد كه تيمار برتـر در وزن ميسوه وابسـته بـهـ نسوع رقـم بـوده و بـهـ تيمارهاى آبيارى بستخى ندارد، بهطورى كه رقم كبكاب در هـر سه سطح مختلف آبيارى برتر بـود و بـهـترتيـب در سـوح VD،

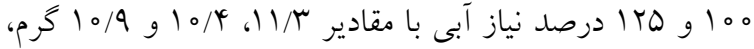
بيشترين وزن ميوه را به خود اختصاص دادند. اين برترى رقمى در صفات قطر و طول ميوه نيز خودنمايى مى كند. بهطـورى كـه ر.

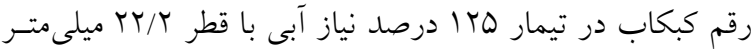
برتر بود و جايگاه نخست را به خود اختصساص داد. در صسفت
بيشتر بودن وزن ميوه رقم كبكاب نسبت بـه دو رقـم ديخـر بـه خصوص رقم خاصى موجب شده تـا تعـداد كـم ميـوه در هـر خوشه را يوشش داده و موجب شود تـا عملكــرد رقـم كبكـاب افزايش بيدا كند. هر جنـــ رقـم كبكـاب، ميـوه كمتـرى در هـر خوشه دارد ولى وزن بالاتر ميوهاش اثر مثبت بر عملكرد كذاشته و تعداد كم ميوه را نسبت به دو رقم ديخر جبران كرده اسـت و ورك روتر به همين دليل ميانخين عملكردهاى سه رقم، اختلاف معنى دارى با هم نداشتند. در صفت خشكيد گى خوشه خرما، رقم كبكـاب با M/A درصد تيمار برتر بـود و بيشـترين درصـد ايـن صـفت نامناسب را به خود اختصاص داد. لازم به ذكر اسـت كـه ارقـام كبكاب و خاصى جزو ارقام مرطوب بوده كه يا بهصسورت تـازه (رطب) مصرف مىشـوند و يـا بهصسورت انبـار شــده (خرمـا) قابليت استفاده دارند. درحالى كه رقم زاهدى جزو ارقام خشـك رك محسوب شده و معمولاً بهصورت خشك مصرف مى شـود. سـه

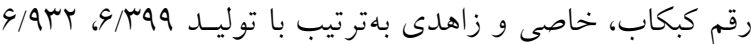


نشريه علوم آب و خاى (علوم و فنون كشاورزى و منابع طبيعى) / سال بيست و سه / شماره اول / بهار \هـ|

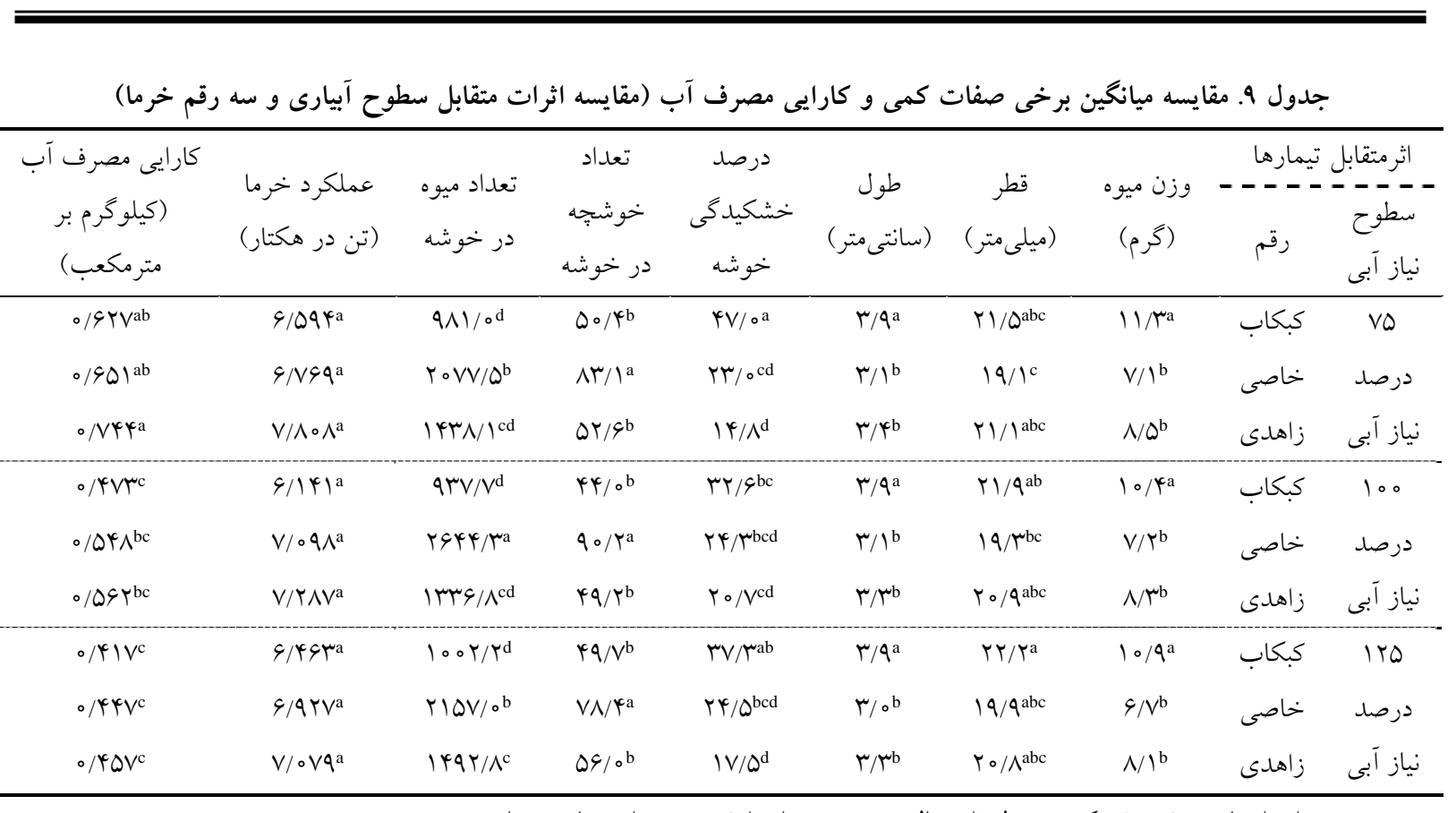

در هر ستون اعداد با حروف مشترى در سطح احتمال ينج درصد، اختلاف معنى دارى با هم ندارند.

اختصاص دادند. در شاخص عملكـــد هـيج تيمـارى بـر ديخـر برترى معنى دارى نداشت و همكى جايخاه يكسانى را بـه خــود اختصاص دادند. در شاخص كارايى مصرف آب رقم زاهدى در

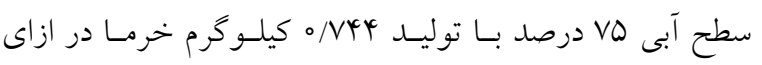
مصرف يك مترمكعب برتر بود و به تنهايى جايگاه نخست را به

خود اختصاص داد (جدول 9). مديريت مصرف آب در سامانه آبيارى قطرهاى زيرسطحى از طريق اعمال ها درصد كم آبيارى جنان مؤثر بود كه اين ميـزان كاهش مصرف آب نسبت به تيمارهايى كه به اندازه مورد نياز و بيش از نياز، آب دريافت كرده را بوشـش داده اسـت. عملكسرد تيمار VD درصد نياز آبى، V/ODV تن در هكتار اندازهگيرى شـد. اين در حالى است كه عملكرد سطوح مـ 100 و هrا درصسد نيـاز

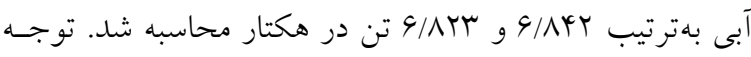
به عملكرد تيمارهاى ه ها و ها ا درصد نياز آبى نسبت به تيمار درصد نياز آبى قطرهاى زيرسطحى مقدارى كاهش را نشـان

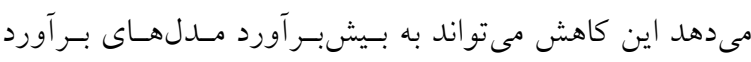
تبخير و تعرق مرتبط باشد. به عبارت ديخر كاربرد كمتـر آب در

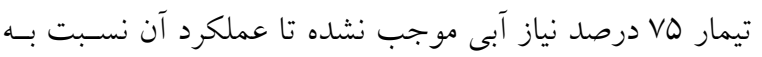

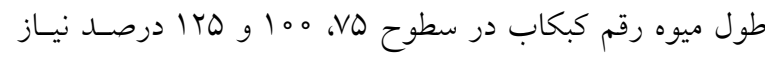

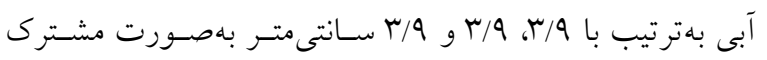
رتبه نخخست را بـه خـود اختصـاص دادنـد. در صـفت درصــ خشكيدكى خوشه، تيمـار برتـر در ايسن صـفت نامناسـب رقـم

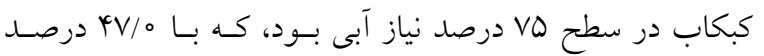

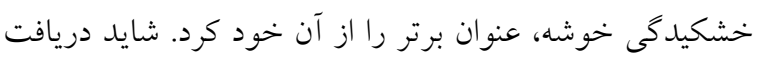
كمتر آب در رقمى كه به رقم مرطوب معسروف اسـت در بـروز اين صفت نامناسب بى تأثير نبوده باشد. در صفت تعداد خوشجه. در خوشه برترى تيمار وابسته به نوع رقم بود بهطورى كه رقـم

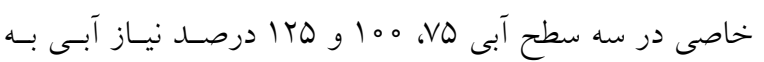

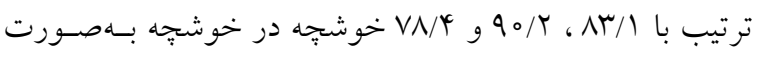
مشترى در رتبه نخست جـاى كرفتنـد. تعـداد خوشسجه بيشـتر تعداد ميوه بيشترى را بههمراه خواهد داشت. لذا در صفت ميوه در خوشه نيز برترى باز هم به نوع رقم وابسته بود. جنانجه رقم

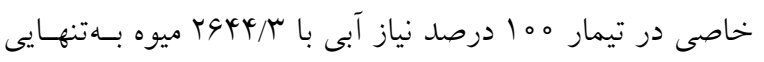
جايگاه نخست را به خود اختصاص داد و يس از آن نيز همسين

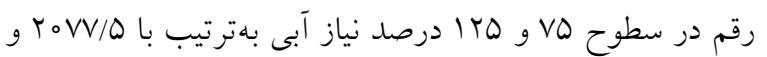

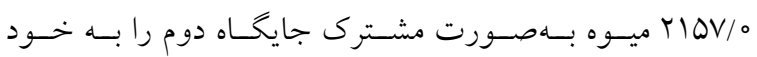


علاوه بر اينكه هم روى صفات كمى از جمله عملكــد و اجـزاى

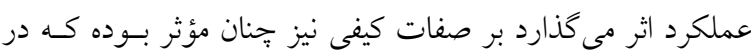

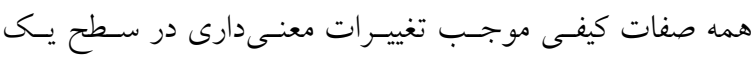
درصد شده است (جدول م1).

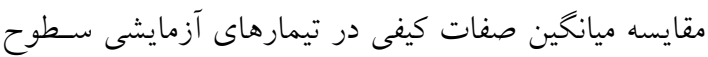

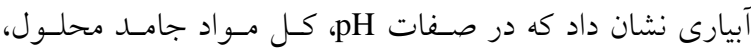

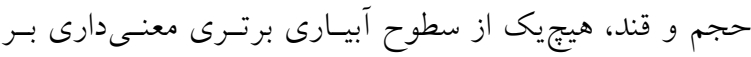

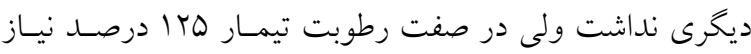

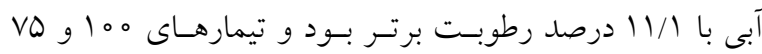

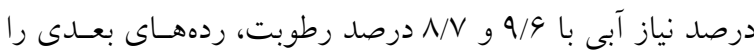

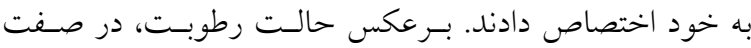
سفتى بافت رخنمايى مى كرد، بلطورى كه بيشترين سفتى بافـت

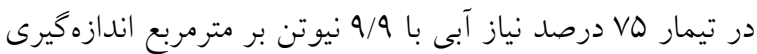

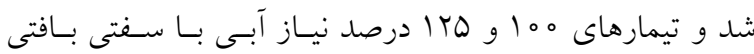

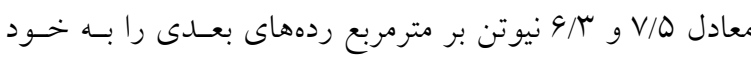
اختصاص دادند. سفتى بافت نشان از كمبود رطوبـت در بافـت فئس

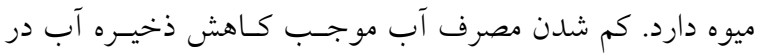

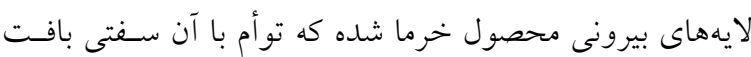

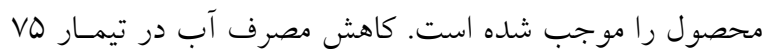

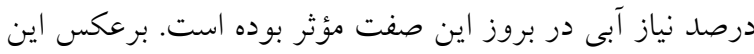

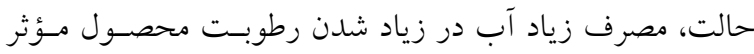

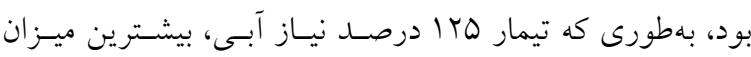

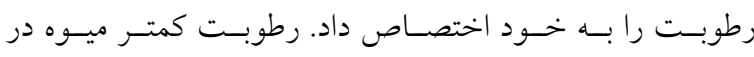
ماند كارى محصول خرما مؤثر است. هرجهه ميزان رطوبت كمتـر

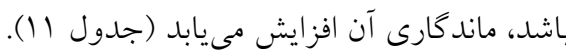

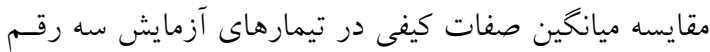

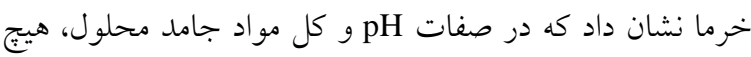

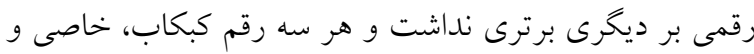

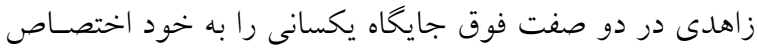

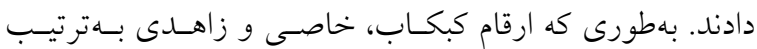
داراى Q

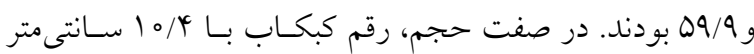

دو سطح ديخر اختلاف معنىدارى داشته باشند و كاربرد آب در

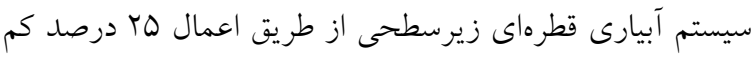

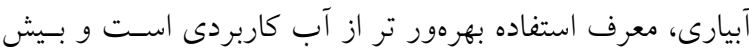

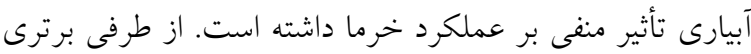

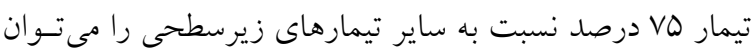

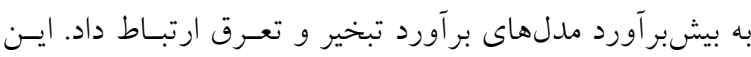

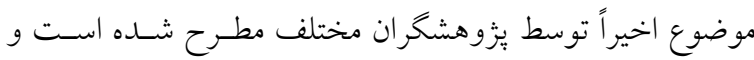

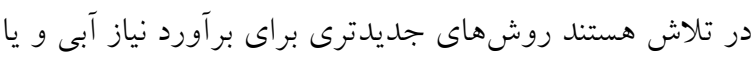

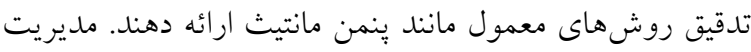

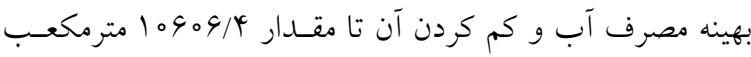

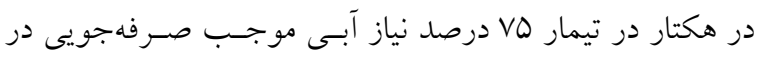

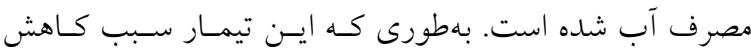

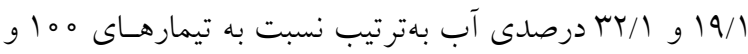

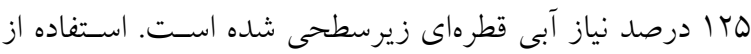

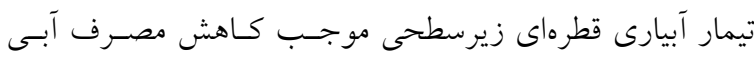

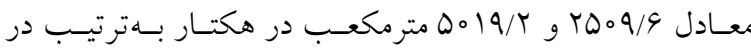

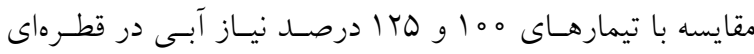
زيرسطى شده است.

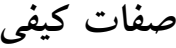

نتايج تجزيه واريانس صفات كيفى نشان داد كه در شـاخص pH، كل مواد جامد محلول، حجم و قند اثر سـطوح آبيـارى معنسى دار

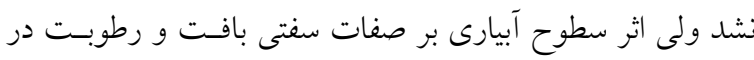

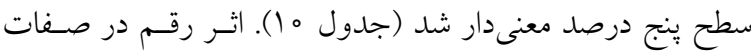
pH

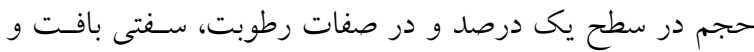

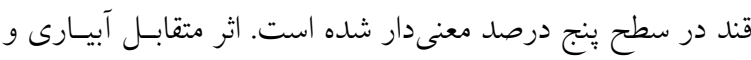
رقم در تمام صفات كيفى معنىدار نشد. ولى برعكس اين حالـت اثر متقابل سال و رقم در تمام صفات كيفى در سطح يـك درصسد معنى دار شد. اين نشانى قوى از تغييرات صفات كيفى در هر سال

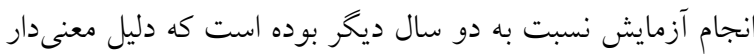

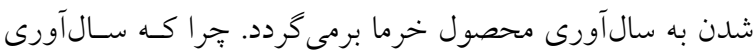


نشريه علوم آب و خاك (علوم و فنون كشاورزى و منابع طبيعى) / سال بيست و سه / شماره اول / بهار 1هـا

\begin{tabular}{|c|c|c|c|c|c|c|c|}
\hline $\begin{array}{c}\text { قند } \\
\text { (mg/ml) }\end{array}$ & $\begin{array}{c}\text { سفتى بافت }\left(\mathrm{N} / \mathrm{m}^{r}\right) \\
\end{array}$ & $\begin{array}{c}\text { رطوبت } \\
(\%)\end{array}$ & $\begin{array}{l}\text { حجم } \\
\left(\mathrm{cm}^{r}\right)\end{array}$ & TSS & $\mathrm{pH}$ & درجه آزادى & منابع تغييرات \\
\hline$\varphi \circ / \uparrow \wedge \Delta^{n . s}$ & $y / \circ V^{n . s}$ & $\left.|V /|\right|^{\text {nn.s }}$ & $r \mu / 9 \wedge^{\text {n.s }}$ & YYG/A & ०/TVGn.s & r & سال \\
\hline $1 / 190^{\mathrm{n} . \mathrm{s}}$ & $r / 01^{*}$ & $1 / q^{n . s}$ & $1 / \wedge \circ$ n.s & $Q / r Q^{n . s}$ & $\circ /\left.\circ \circ\right|^{n . s}$ & 9 & تكرار \\
\hline $\mid r / \mathcal{Y} \wedge \circ$ n.s & $q_{0} / r^{*}$ & $Y \circ / Y^{*}$ & $19 /$ ren.s & $1 \circ / 9 \Delta^{\text {n.s }}$ & $\circ / / V^{n . s}$ & r & آبيارى \\
\hline$\circ / \mu q \Delta^{n . s}$ & $10 / 44^{* *}$ & $4 / \Lambda \Lambda^{*}$ & $\Lambda \mathscr{Y} /\left.\backslash\right|^{\mathrm{n} . \mathrm{s}}$ & $r / \mu_{\circ}$ n.s & $\circ / \circ Y^{* *}$ & $\varphi$ & سال × آبيارى \\
\hline r/9Vo & 1/^9 & $1 / 4 \pi$ & $1 / \mu_{Y}$ & $N / \circ \Delta$ & ०/०० & Ir & خطا \\
\hline$r q / v r r *$ & $r T Q / \circ r^{*}$ & $\Delta Q / Y r^{*}$ & $9 Y / \circ V^{* *}$ & $\mid Q V / \& q^{n . s}$ & $\circ / 091^{n . s}$ & r & رقم \\
\hline$V / 119^{* *}$ & $01 / 9 Y^{* *}$ & $19 / 90^{* *}$ & $Q / \circ \Delta^{* *}$ & $\Lambda 1 / \circ Q^{* *}$ & $\circ / \bigwedge \wedge V^{* *}$ & q & سال× رقم \\
\hline$r / / 99^{n . s}$ & $\varphi / \circ q^{n . s}$ & $9 / \mathrm{VV} \cdot \mathrm{n}$ & $\circ / V Y^{\mathrm{n} . \mathrm{s}}$ & $1 / 9 V^{n . s}$ & $\circ / 019^{n . s}$ & 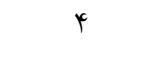 & آبيارى×رقم \\
\hline r/イ & $r Y / 99^{* *}$ & $r / 9 \circ$ n.s & $1 / \circ 9$ n.s & $\varphi / \circ \varphi$ n.s & $\circ / \circ \circ \wedge^{\mathrm{n} . \mathrm{s}}$ & $\wedge$ & سال×آبيارى × رقم \\
\hline ס & $1 / 99$ & $1 / \wedge t$ & $\circ / 90$ & $r / \mathcal{L Q V}$ & $0 / 009$ & re & خطا \\
\hline$r / \circ \mathrm{V}$ & IV/AY & Ir/AG & $11 / \pi \mathrm{V}$ & $\varphi / 09$ & $1 / 90$ & - & ضريب تغييرات \\
\hline
\end{tabular}

*** : اختلاف معنى دار در سطح يكى درصد *: اختلاف معنى دار در سطح ينج درصد و ns اختلاف معنىدارى وجود ندارد .

جدول 11. مقايسه ميانگين برخى صفات كيفى در تيمارهاى آزمايشى سطوح آبيارى

\begin{tabular}{|c|c|c|c|c|c|c|}
\hline $\begin{array}{c}\text { قند } \\
\text { (mg/ml) }\end{array}$ & $\begin{array}{c}\text { سفتى بافت } \\
\left(\mathrm{N} / \mathrm{m}^{r}\right)\end{array}$ & $\begin{array}{c}\text { رطوبت } \\
(\%)\end{array}$ & $\begin{array}{l}\text { حجم } \\
\left(\mathrm{cm}^{r}\right)\end{array}$ & TSS & $\mathrm{pH}$ & سطوح آبيارى \\
\hline$\Delta \varphi / \wedge^{\mathrm{a}}$ & $9 / 9^{a}$ & $\Lambda / V^{b}$ & $\mathrm{~V} / \wedge^{\mathrm{a}}$ & $q Y / q^{a}$ & Q/A Y & Vه درصد نياز آبى VD \\
\hline$\Delta \varphi / 0^{a}$ & $\mathrm{~V} / \mathrm{Q}^{\mathrm{ab}}$ & $9 / q^{a b}$ & $\Lambda / \mu^{a}$ & $G Y / I^{\mathrm{a}}$ & $\Delta / V^{a}$ & هـ الدرصد نياز آبى \\
\hline$\Delta \omega / \Delta^{\mathrm{a}}$ & $9 / \mu^{\mathrm{b}}$ & $11 / /^{a}$ & $q / Y^{a}$ & $91 / \mathrm{V}^{\mathrm{a}}$ & $0 / 99^{a}$ & هr ادرصد نياز آبى \\
\hline
\end{tabular}

بر صفت pH معنى دار نشد، ولى مقايسه ميانخين اثـرات متقابـل نشان داد كه دريافت آب كمتر در اسيدى شدن ميوه مـؤثر بـوده است هر جّند اين اثر معنىدار نبوده است بهطورى كه صرفنظر از نوع رقم، بيشترين مقادير pH در تيمارهاى VD درصد نياز آبى

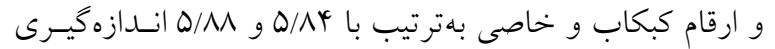
شدند. اسيدى شدن در ماندكارى محصـول اثتر معكـوس دارد. توجه به اين صفت نشان مىدهد كه كمترين pH به تيمسار هار درصد نياز آبى و بيشترين آن به سطح VD درصد نياز آبى تعلـق كرفت كه شايد كاهش مصرف آب در افزايش ميزان pH بى تأثير نباشد. بهعبارت ديخر كاهش مصرف آب موجب افزايش ميزان محصول مى شود. در صفت كل مواد جامد محلول (TSS)،
مكعب برتر بود و بهتنهايى رده نخست را بـه خـود اختصـاص داد. اين برترى رقمى كبكاب در صفت رطوبت نيـز خودنمـايى مى كرد بهطورى كه رقـم كبكـاب بـا آ11/ درصـد رطوبـت در جايگاه نخسـت بـوده و ردههـاى بعـدى بـا 9/0 و N/D درصـد رطوبت بـهترتيـب بـهـ ارقـام زاهـدى و خاصسى تعلـق كرفـت. بيشترين سفتى بافت به رقم زاهدى با 1/9 إنيوتن بـر مترمربـع تعلق گرفت كه بهتنهايى رده نخست را از آن خود كرد. كمترين

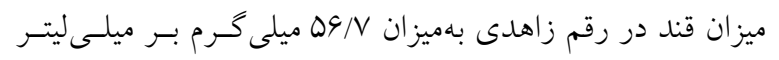

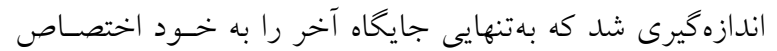

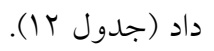
هر جِند نتايج تجزيه واريانس اثرات متقابـل آبيـارى و رقـم 
جدول Y I. مقايسه ميانخين برخى صفات كيفى در تيمارهاى آزمايشى سه رقم خرما

\begin{tabular}{|c|c|c|c|c|c|c|}
\hline $\begin{array}{c}\text { قند } \\
\text { (mg/ml) }\end{array}$ & سفتى بافت & رطوبت & حجم & TSS & $\mathrm{pH}$ & رقم \\
\hline$\Delta V / \circ^{a}$ & $\mathrm{Q} / \mathrm{V}^{\mathrm{b}}$ & $11 / 4 a$ & $10 / y^{a}$ & $s \varphi / V^{a}$ & $\Delta / v q^{a}$ & كبكاب \\
\hline$\Delta \mathcal{Q} / \Delta^{\mathrm{a}}$ & $c / 1^{b}$ & $\Lambda / \Delta^{\mathrm{b}}$ & $G / 1^{b}$ & $G Y / /^{a}$ & $\Delta / v q^{a}$ & خاصى \\
\hline$\Delta Y / V^{b}$ & $11 / 9^{a}$ & $9 / \Delta^{\mathrm{ab}}$ & $V / q^{b}$ & $\Delta q / q^{a}$ & $\Delta / V_{\circ}{ }^{a}$ & زاهدى \\
\hline
\end{tabular}

جدول rا. مقايسه ميانكين برخى صفات كيفى (مقايسه اثرات متقابل سطوح آبيارى و سه رقم خرما)

\begin{tabular}{|c|c|c|c|c|c|c|c|}
\hline $\begin{array}{c}\text { قند } \\
\text { (mg/ml) }\end{array}$ & سفتى بافت & $\begin{array}{c}\text { رطوبت } \\
(\%)\end{array}$ & $\begin{array}{l}\text { حجم } \\
\left(\mathrm{cm}^{3}\right)\end{array}$ & TSS & $\mathrm{pH}$ & 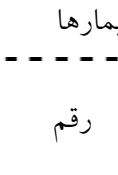 & - - - - - - - \\
\hline$\Delta \Lambda / Y^{a}$ & $\mathrm{~V} / \mathrm{I}^{\mathrm{de}}$ & $10 / V^{a b}$ & $9 / \Delta^{b c}$ & $9 \omega / \wedge^{\mathrm{a}}$ & $\Delta / \Lambda Y^{\mathrm{ca}}$ & كبكاب & \multirow{3}{*}{ نياز آبى } \\
\hline$\Delta V / Y^{\mathrm{ab}}$ & $\Lambda / q^{c d}$ & $9 / V^{c}$ & $9 / \mu^{\mathrm{e}}$ & $G Y / \wedge^{a b c}$ & $\Delta / \Lambda^{\mathrm{a}}$ & خاصى & \\
\hline$\Delta r / \Lambda^{c d}$ & $1 \mathrm{r} / \mathrm{V}^{\mathrm{a}}$ & $\Lambda / V^{b c}$ & $V / T^{\text {de }}$ & $9 \circ / T^{c}$ & $\Delta / V Q^{\mathrm{ab}}$ & زاهدى & \\
\hline$\Delta \& / q^{a b}$ & $0 / q^{e}$ & $11 / \mathrm{A}^{\mathrm{a}}$ & $10 / T^{\mathrm{ab}}$ & $q 4 / q^{\mathrm{ab}}$ & $\omega / \Lambda \circ^{a}$ & كبكاب & \multirow{3}{*}{ نياز آبى } \\
\hline$\Delta G / Y^{\mathrm{bc}}$ & $\Delta / 1^{e}$ & $\Lambda / 0^{c}$ & $9 / 9 \mathrm{e}$ & $G Y / 1^{b c}$ & $\Delta / V q^{a b}$ & خاصى & \\
\hline$\Delta Q / \circ^{c d}$ & $11 / \wedge^{\mathrm{ab}}$ & $9 / 1^{b c}$ & $\Lambda /\left.\right|^{\text {cde }}$ & $\Delta Q / \Delta^{c}$ & $\Delta / V q^{a b}$ & زاهدى & \\
\hline$\Delta G /\left.\right|^{b c d}$ & $\boldsymbol{y} / \boldsymbol{\mu e}^{\mathrm{e}}$ & $11 / \wedge^{a}$ & $11 / \Delta^{a}$ & $q^{r} / V^{\mathrm{ab}}$ & Q/VGab & كبكاب & \multirow{3}{*}{ نياز آبى آ } \\
\hline$\Delta Q / q b c d$ & $\varphi / \varphi^{e}$ & $10 / \wedge^{\mathrm{ab}}$ & $\mathrm{V} / \mathrm{Y}^{\text {ede }}$ & $91 / 4 b c$ & $\Delta / V Y^{\mathrm{ab}}$ & خاصى & \\
\hline$\Delta r / 4 d$ & $10 / \gamma^{\mathrm{bc}}$ & $10 / \wedge^{\mathrm{ab}}$ & $\Lambda / q^{\text {bcd }}$ & $\Delta q / q^{c}$ & $\Delta / \Delta Q^{b}$ & زاهدى & \\
\hline
\end{tabular}

حجم، تيمار 1Tه درصد نياز آبى و رقم كبكاب بـا ميـزان 11/1 سانتىمترمكعب تيمار برتر بود. اين در حسالى اسـت كـه تيمـار

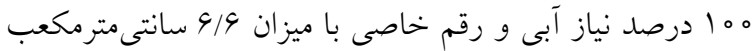

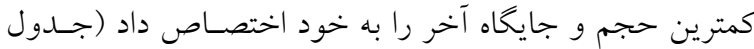
ץ||). حجم ميوه متأثر از اندازه و وزن ميوه است بـهــورى كـهـ كمترين حجم ميوه صرفنظر از سطوح مختلف نيازهاى آبى بــه مئس رقم خاصى در سطوح مختلف تعلق گرفته است. در مورد ميزان

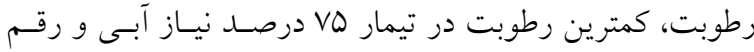
خاصى بهميزان 9/V درصد بهثبت رسيد. كم بودن رطوبت نقشـ

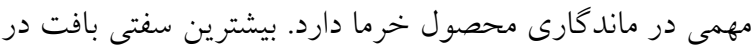

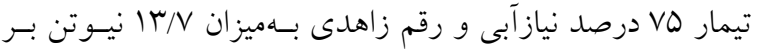

برترى از آن تيمار VQ درصد نياز آبى و رقـم كبكـاب بـهميـزان 90/1 بود كه بهتنهايى جايگاه نخست را به خود اختصـاص داد. كاهش مصرف آب در تيمار VQ درصد نياز آبى موجب كـاهش رطوبت محصول شده و از اين طريق در افزايش كل مواد جامد محلول مؤثر بوده است و هرجها مواد جامد محلول بيشتر شـوند ماندكارى محصول بالاتر مىرود. هميجنين افـزايش مـواد جامــــ محلول در رقم كبكاب بيش از ارقام خاصى و زاهدى است كـهـ از اين بابت بين رطوبت ميوه و كل مـواد جامـــ محلـول رابطـهـ

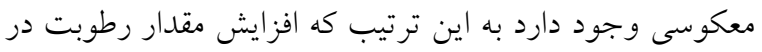
رقم كبكاب موجب افزايش بيشتر مواد جامد محلول نسـبت بـهـ دو رقم خاصى و زاهـدى شـده اسـت (جــدول با). در مـورد 
ن آن تا مقدار نياز آبى موجب صرفهجويى در مصرف آب شده است. بهطورى

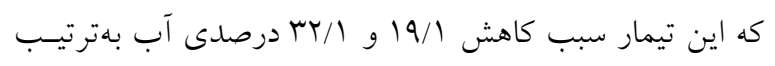
نسـبت بـه تيمارهـاى ه ما و ه ا ا درصسد نيـاز آبسى قطـرهاى زيرسطحى شده است. اخر مبناى مقايسه ميـزان آب دريـافتى در تيمار ه ما درصد نياز آبى درنظر كرفته شود، اسـتفاده از تيمـار آبيارى قطرهاى زيرسطحى موجب كاهش مصسرف آبسى معسادل

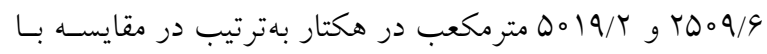
تيمارهاى 0010 و ه ا درصد نياز آبسى در قطـرهاى زيرسـطى شده است. توجه به عملكرد تيمارهاى ه ما و ها ا درصد نيساز

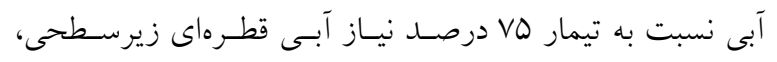
مقدارى كاهش را نشان مىدهد. اين كـاهش مسىتوانـد بـهدليل مصرف زياد آب باشد، بهطورى كه اثر معكسوس و كاهشى بـر عملكرد كذاشته است. ممكن است آبيارى زياد موجب برشـدن

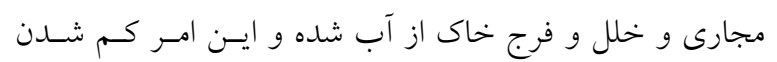
تنفس ريشه را در بيى داشته باشد و كـاهش اكسـيزن خـاك اثـر كاهشى بر عملكرد كذاشته است. مديريت بهينه مصسرف آب در تيمار ه V درصد نياز آبى از طرفى از هــدر رفـت آب از طريسق

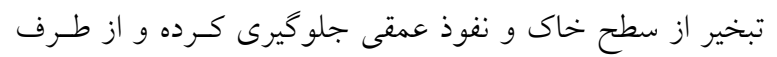
ديخر موجب افزايش كـارايى مصـرف آب در ايسن تيمـار شـده است. با توجه به عدم وجود تفاوت معنىدار بين سطوح آبيارى

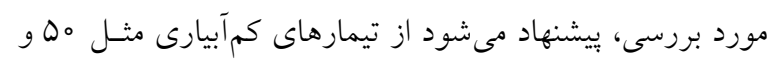

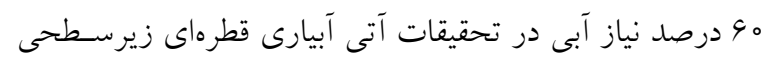
استفاده شود.
مترمربع اندازه گيرى شد. در صفت قند برترى به تيمارهاى ه و

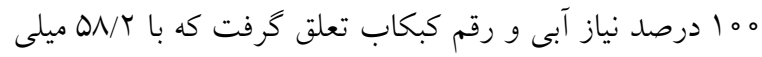
گرم بر ميلى ليتر بهتنهايى در جايخاه نخست قرار گرفت. افزايش مصرف آب در كاهش ميزان قند محصول مؤثر بوده باشـــ جــرا

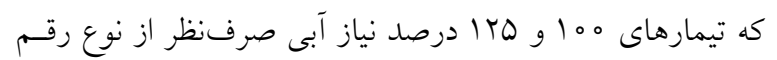
نسبت به تيمار VD درصد نياز آبى، كمترين ميزان قند را به خود

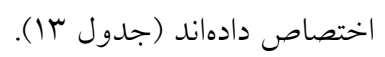
از يك سو سـفتى و ميـزان رطوبـت ميـوه خرمـا دو رابطـهـ عكس با هم دارند و از سـوى ديخــر تيمـارى كـه آب بيشـترى

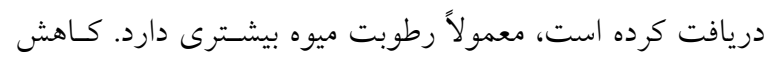
آب دريافتى در تيمارهاى آبيارى موجب افزايش قند ميوه شــه است. همجينين نتايج نشان داد تيمارى كه آب كمتـرى دريافـت كرده، خاصيت اسيديته آن كاهش يافته است. لـذا بـا توجسه بــه اينكه هر جّه اسيد ميوه كمتـر شـود ميسوه ديرتـر تـرش شـــه و

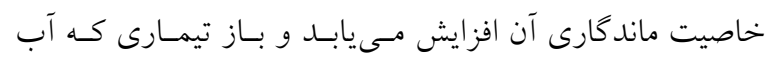
كمترى دريافت كرده، مواد جامد آن افزايش يافتسه اسـت، يسس إنس افزايش مواد جامد همانـــد اسـيديته كمتـر ميـوه، در مانـدكارى خرما و دير ترش شدن آن مؤثر است. يُ بنابراين نتيجه كيـرى

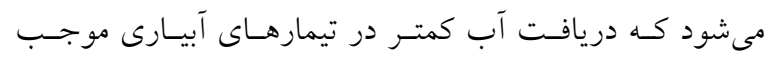
رطوبت كمتر ميوه، سفتى بيشتر، اسيديته كمتر، قند بالاتر ميوه و افزايش مواد جامد محلول خرما شده است. نتيجه گيرى نتايج اين تحقيق نشان داد مديريت بهينه مصرف آب و كم كـرد

\section{منابع مورد استفاده}

1. Agricultural Statistics. 2014. Volume I: Garden Products. Crop year Ministry of Agriculture-Jahad, Deputy Planning and Economics. Bureau of Statistics and Information Technology. Iran. (In Farsi).

2. Alihouri, M. and P. Tishehzan. 2011. The Following Watering Schedule- Strategic Plan Palm Sector in the Country. Kerdegar Press, Ahvaz. (In Farsi).

3. Allen, R. G., L. Pereira, D. Raes and M. Smith. 1998. Crop evapotranspiration: Guidelines for computing cropwater requirements. FAO Irrigation and Drainage Paper 56, Rome, Italy.

4. Al-Rumaih, M. and M. A. Kassem. 2003. The effect of irrigation interval on the yield and quality of palms dates. The Canadian Society for Engineering in Agricultural, Food and Biological Systems Meeting. Montreal, Conada. PP: 43-58.

5. Ahmed, T. F., H. N. Hashmi and A. R. Ghumman. 2011. Performance assessment of subsurface drip irrigation 
system using pipes of varying flexibility. Mehran University Research Journal of Engineering and Technology 30(3): 361-370.

6. Al-Amoud, A. I., S. Fawzi, A. Mohammad Saad. A. Al-Hamed and M. Ahmed. 2000. Reference evapo-transpiration and date palm water use in the Kingdom of Saudi Arabia. International Research Agricultural Science and Soil Science 2(4): 155-169.

7. Al-Zaidi, A. A., M. B. Baig, E. A. Elhag and M. A. Al-Juhani. 2013. Farmers Attitude Towards the Traditional and Modern Irrigation Methods in Tabuk Region - King-Dom of Saudi Arabia. Chapter 8. In Science, Policy and Politics of Modern Agricultural System: Global Context to local Dynamics of Sustainable Agriculture. Springer Science+Business. US.

8. AOAC. 1990. Official Methods of Analysis, 15thedn. Association of Official Analytical Chemists, Washington, D. C.

9. Darfaoui, C., A. El-Mostafa and A. Al-Assiri. 2010. Response to climate change in the Kingdom of Saudi Arabia. A Report Prepared for FAO-RNE. Available online at: http://www.fao.org/forestry/291570d03d7abbb7f341972e8c6ebd2b25a181.pdf

10.FAO. 2002. Date palm cultivation. FAO Plant production and protection paper 156 rev. 1. Food and Agriculture organization of the United Nations, Rome, Italy.

11.FAO. 2009. Water and agriculture in Saudi Arabia. AQUASTAT - FAO's Information System on Water and Agriculture. Food and Agriculture organization of the United Nations. Available online at: http://www.fao.org/nr/water/aquastat/countries/saudi_arabia/index.stm; Accessed on March 28, 2013.

12. Farzamneya, M. and Z. Ravari. 2005. The effects of deficit irrigation on yield and water use efficiency Mazafati date in Bam city. Scientific Journal of Agriculture 28(1): 79-86. (In Farsi).

13.Foakwa, E. O., A. Paterson, M. Fowler and J. Vieira. 2008. Particle size distribution and compositional effects on textural properties and appearance of dark chocolates. Food Engineering 87: 181-190.

14. Ghafarinejad, A. 2001. Research Project to Determine the Best Speed and Depth of Drip Irrigation Method Mazafati Palm. City of Bam: Kerman Agricultural and Natural Resources Research and Education Center. Kerman. (In Farsi).

15. Hosseini, Z. 1990. Conventional Methods for Food Analysis. Shiraz University Press. Shiraz. (In Farsi).

16.KACST. 2012. Strategic Priorities for agricultural research. King Abdulaziz City for Science and Technology. Ministry of conomy and Planning, Doc. No. 40P0001-PLN-0001-er01. Kingdom of Saudi Arabia. Available online at: http://nstip.kacst.edu.sa/cs/groups/public/documents/document/edisp/agricul-turetech.pdf

17.Karami, E. 2006. Appropriateness of farmers' adoption of irrigation methods: The application of AHP model. Agricul-Tural Systems 87: 101-119.

18.Liebenberg, P. J. and A. Zaid. 2002. Date Palm irrigation. Chapter 7. In. Date palm cultivation. Plant Production Paper 156 rev.1. Food and Agriculture organization of the United Nations (FAO). Rome, Italy.

19. Oron, G., J. Demalach, Z. Hoffman and R. Cibotaru. 1991. Subsurface microirrigationwith effluent. Irrigation and Drainage Engineering -ASCE 117: 25-36.

20.PHene, C. J. 1995. Sustainability and potential of subsurface drip irrigation. In: Proceedings of the Fifth International Micro Irrigation Congress, Orlando, Florida, pp. 359-367.

21. Rastegar, H. and H. Zargari. 2011. Effects of water stress on yield and quality of Shahani date. In: Proceeding of the $7^{\text {th }}$ Congress of Horticultural Sciences. Iran, Isfahan University of Technology. Isfahan. PP: 1608-1610. (In Farsi).

22. Sepahvand, M. 2009. Comparing water requirements, water productivity and economic productivity of wheat and canola in the West of the country in wet years. Journal of Iran Water Research 3(4): 63-68. (In Farsi).

23. Sivanappan, R. K. 1998. Low cost micro irrigation system for all crops and all farmers. In: Proceedings of the Workshop Micro irrigation and Sprinkler irrigation Systems, New Delhi.

24. Mohebbi, A. 2005. The effects of water on the surface and drip techniques on yield and quality traits Piarom date. Journal of Soil and Water Sciences 19:1. 124-130. (In Farsi).

25. Mohebi, A. and M. Alihouri. 2013. The effect of depth and irrigation on the productivity, yield and vegetative Palm Piarom. Journal of Agricultural Water 27(4): 455-464. (In Farsi). 


\title{
Irrigation Management of Subsurface Drip Irrigation of Palm Trees under Arid and Semiarid Regions
}

\author{
N. Salamati ${ }^{*}$, H. Dehghanisanij ${ }^{2}$ and L. Behbahani ${ }^{3}$
}

(Received: February 4-2017 ; Accepted: April 18-2018)

\begin{abstract}
In order to investigate the effect of water quantity in subsurface drip irrigation on water use efficiency of palm yield and yield components, and determining suitable irrigation treatments for three different date cultivars, a split plot experiment design in a randomized complete block design with three replications were applied for three cropping years (2013-2016), at Behbahan Agricultural Research Station. The applied irrigation water in three levels based on 75, 100 and 125 percent of water requirement in the main plots and three cultivars of Kabkab, Khasi and Zahidi dates were compared in sub plots. The irrigation level of $75 \%$ with $0.646 \mathrm{~kg}$ of dates per 1 cubic meter of water in terms of water use efficiency as compared to the other two levels of irrigation showed a significant superiority. The Khasi cultivar with 83.9 pips and 29.2929 fruits in the cluster ranked first. The irrigation level of $125 \%$ with $11.1 \%$ were higher in fruit moisture, and $100 \%$ and $75 \%$ irrigation levels with $9.6 \%$ and $7.8 \%$ moisture content were the next. The irrigation level of $125 \%$ for Kabkab cultivar with a volume of 11.1 cubic centimeters were ranked first. Optimizing water use and reducing it to 10606 cubic meters per hectare in irrigation level of $75 \%$ water treatment will save water consumption. If the basis for comparing the amount of water used in $100 \%$ water treatment is considered, then the use of subtropical drip irrigation reduces water consumption by 2509.6 and 5019.2 cubic meters per hectare, respectively, compared to 100 and $125 \%$ water requirements.
\end{abstract}

Keywords: Yield, Water use efficiency, Palm

1. Research Assistant Professor of Agricultural Engineering Research Department, Khuzestan Agricultural and Natural Resources Research and Education Center, Agricultural Research, Education and Extension Organization (AREEO), Ahvaz, Iran.

2. Associate Professor, Agricultural Engineering Research Institute (AERI), Agricultural Research Education, and Extension Organization (AREEO), Karaj, Iran.

3. Researcher of Food Industry, Agricultural Engineering Research Department, Khuzestan Agricultural and Natural Resources Research and Education Center, Agricultural Research, Education and Extension Organization (AREEO), Ahvaz, Iran.

*: Corresponding Author, Email: nadersalamati@yahoo.com 